\title{
THE MA-10 CELL LINE AS A MODEL OF insl3 REGULATION AND LEYDIG CELL FUNCTION
}

\author{
A Thesis \\ presented to \\ the Faculty of California Polytechnic State University, \\ San Luis Obispo
}

\author{
In Partial Fulfillment \\ of the Requirements for the Degree
}

Master of Science in Agriculture with Specialization in Animal Science

by

Mary Elizabeth Strong

June 2011 
(C) 2011

Mary Elizabeth Strong

ALL RIGHTS RESERVED 


\section{COMMITTEE MEMBERSHIP}

TITLE: The MA-10 Cell Line as a Model of insl3 Regulation and Leydig Cell Function

AUTHOR: Mary Elizabeth Strong

DATE SUBMITTED: June 2011

COMMITTEE CHAIR: Daniel G. Peterson Ph.D, Associate Professor

COMMITTEE MEMBER: Matthew A. Burd M.S., D.V.M., Associate Professor

COMMITTEE MEMBER: Russell C. Hovey Ph.D, Associate Professor 


\begin{abstract}
The MA-10 Cell Line as a Model of insl3 Regulation and Leydig Cell Function Mary Elizabeth Strong
\end{abstract}

Leydig cells produce testosterone in response to luteinizing hormone ( $\mathrm{LH})$ via the cyclic adenosine monophosphate (cAMP)/protein kinase A pathway. Additionally, these cells are responsible for producing insulin-like peptide 3 (INSL3), a peptide hormone that is essential for testicular descent. The insl3 promoter in Leydig cells can be activated by cAMP through the transcription factor Nur77, which has also been shown to regulate the promoters of the steroidogenic enzymes, cypl7 and $3 \beta$-hsd. While the mechanism of LH action on testosterone production is well characterized, the effect of LH on insl3 abundance has yet to be shown directly. The MA-10 Leydig cells treated with hCG exhibited a transient and robust increase in nur 77 mRNA, while insl3 mRNA abundance remained unchanged. Further, cAMP failed to affect insl3 mRNA, though nur77 mRNA abundance was significantly increased. Inhibition of LH-receptor-linked signal transduction pathways in the presence of hCG implicated multiple signaling networks in the regulation of both insl3 and nur77. Treatment with hCG or cAMP did not affect the abundance of $3 \beta$-hsd mRNA. Interestingly, though the MA-10 cell line has been reported to lack CYP17 activity and mRNA and so produce progesterone instead of testosterone, cyp17 mRNA was present and inducible by hCG and cAMP. The addition of hCG, testosterone, nor the combination of hCG and testosterone affected insl3 mRNA abundance. Though hCG consistently increased nur77 mRNA abundance, the addition of testosterone did not enhance the effects of hCG. Collectively, these results indicate that insl3 is regulated by factors other than LH/CG and cAMP in the MA-10 cell line. 


\section{ACKNOWLEDGEMENTS}

I am forever indebted to Dr. Dan Peterson, for his unwavering support, sense of humor and uncanny ability to design mini-experiments. To Dr. Matt Burd for his unconventional but helpful guidance. To my fellow graduate students: Tasha, Lisa,

Laura, Michael and Hannah for being my partners in crime (and in science). And lastly, to my father who sat next to me while I ate the elephant. 


\section{DEDICATION}

This thesis is dedicated to Big Gunns, who read all of my first drafts. 
LIST OF TABLES .............................................................ii

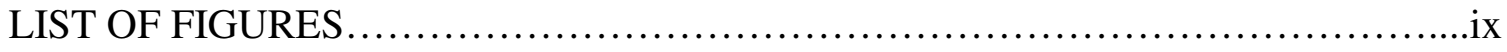

\section{CHAPTER}

1. Literature Review

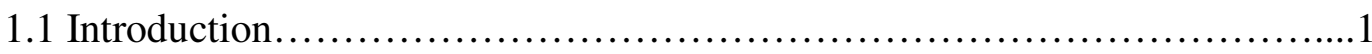

1.2 Sexual Development of Male Mammals..................................2

1.3 Development of the Hypothalamic-Pituitary Gonadal Axis......................3

1.4 Leydig Cell Development and Differentiated Function.......................5

1.5 Testicular Descent.................................................... 9

1.6 Cryptorchidism....................................................... 11

1.7 Luteinizing Hormone and Chorionic Gonadotropin.........................14

1.8 Insulin-like Peptide 3 (INSL3) .........................................17

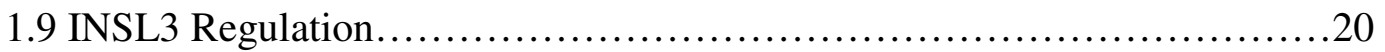

1.10 MA-10 Cell Line...................................................24

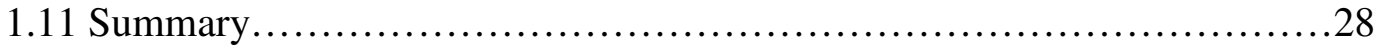

2. The MA-10 Cell Line as a Model of insl3 Regulation and Leydig Cell Function

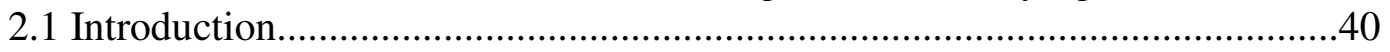

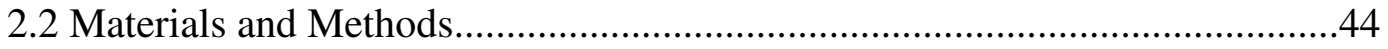

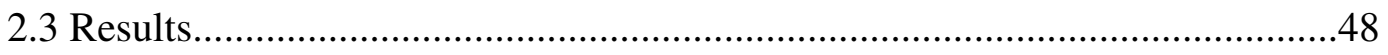

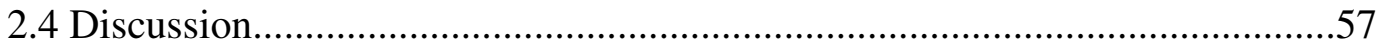

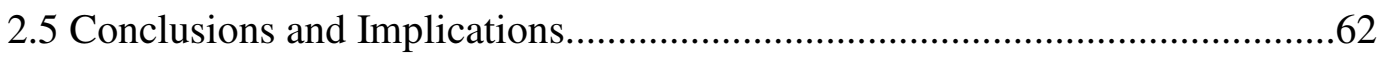

2.6 Reconciliation and Future Investigations.....................................................64

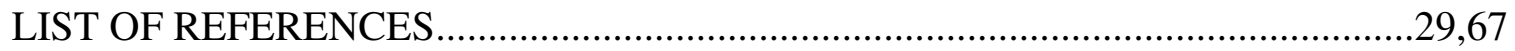




\section{LIST OF TABLES}

Table $\quad$ Page

1. Gene specific primers for quantitative polymerase chain reaction...........................47 


\section{LIST OF FIGURES}

$\begin{array}{lll}\text { Figure } & \text { Page }\end{array}$

1. The effect of LH/hCG on insl3 and nur77 mRNA abundance.................................51

2. The effect of hCG and pathway inhibition on insl3 and nur77 mRNA abundance.......52

3. The effect of cAMP analogs on insl3 and nur77 mRNA abundance..........................53

4. The effect of $(\mathrm{Bu})_{2}$-cAMP on insl3 and nur77 mRNA abundance at four different

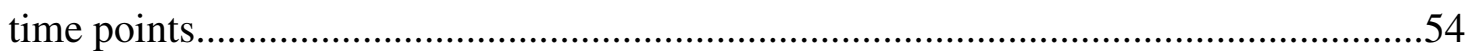

5. The effect of hCG and cAMP on $3 \beta$-hsd and cyp17 mRNA abundance......................55

6. The effect of hCG and testosterone on insl3 and nur77 mRNA abundance.................56 


\section{CHAPTER 1}

\section{Literature Review}

\subsection{Introduction}

The Leydig cells of the testes mediate male sexual development through the production of two hormones: testosterone and insulin-like peptide 3 (INSL3). During

fetal development, testosterone is essential to the development of the external genitalia, the masculinization of the male duct system and the descent of the testes into the scrotum. During puberty, testosterone promotes further masculinization and initiates spermatogenesis and in adults, testosterone maintains spermatogenesis [1]. INSL3, also produced by the Leydig cells of testes, is essential for normal testicular descent to occur in fetal life and serves as a germ cell survival factor in adulthood [2, 3]. The descent of the testicles into the scrotum is a vital step in normal male sexual development in most mammalian species, as the scrotum provides a temperature that is $2-8^{\circ} \mathrm{C}$ lower than the body cavity, which is essential for maintenance of normal spermatogenesis and fertility $[4,5]$. Cryptorchidism, or the failure of one or both of the testes to descend into the scrotum, is a common congenital abnormality that affects $2-8 \%$ of human male neonates [6]. Retention of the testes in the body cavity and their maintenance at that higher temperature is not only detrimental to fertility, but can also increase the risk of developing testicular cancer $[7,8]$. The potential causes of cryptorchidism remain to be elucidated, in part because the intricate network of intra- and intercellular signaling pathways that mediate testicular descent have yet to be fully characterized. The objective of this review is to detail the factors that have been identified as modulators of testicular descent in an effort to highlight those areas that still warrant investigation. 


\subsection{Sexual Development of Male Mammals}

The fundamental determinant of the male sex in mammals is the inheritance of a Y-chromosome at the time of fertilization. The Y-chromosome contains the sexdetermining region Y (SRY) gene which, when activated, initiates testis development [911]. Sertoli cells are the first cell type to differentiate in the developing gonad and are thought to be responsible for inducing further differentiation of the testis. These events include the regression of the Müllerian ducts mediated by anti-Müllerian hormone $(\mathrm{AMH})$, development of the testicular cords and interstitium and the differentiation of Leydig cells [9]. Once the Leydig cells have differentiated and are capable of hormone production and secretion, further virilization of the male reproductive tract ensues. As the Müllerian ducts regress, the Wolffian ducts develop and eventually differentiate into the epididymis, vas deferens and seminal vesicles under the control of Leydig cellderived testosterone $[1,12]$. Subsequent to those events, further masculinization such as the development of external genitalia and descent of the testes into the scrotum completes the in utero portion of male sexual development, with further developmental and hormonal changes taking place during puberty $[11,13]$. 


\subsection{Development of the Hypothalamic-Pituitary-Gonadal Axis:}

The hypothalamic-pituitary-gonadal (HPG) axis is the central control entity for sexual development, differentiation and the reproductive functions therein. Gonadotropin releasing hormone $(\mathrm{GnRH})$ is secreted by the hypothalamus in a pulsatile manner into the hypothalamic-hypophyseal portal system, a specialized capillary network that is connected to the pituitary gland. This network prevents GnRH from traveling through the systemic circulation, making the pituitary the primary target of this hormone. Gonadotropic cells in the anterior pituitary express the GnRH receptor and produce follicle-stimulating hormone (FSH) and luteinizing hormone (LH) in response to $\mathrm{GnRH}$ stimulation. FSH and LH are glycoprotein hormones that bind to their individual Gprotein coupled receptors (GPCR) on testicular Sertoli and Leydig cells to regulate spermatogenesis and steroidogenesis [1].

During gestation, the hypothalamus is the first component of the HPG system to develop. Initial $\mathrm{GnRH}$ production coincides with the development of the anterior pituitary. Interestingly, the onset of testosterone synthesis precedes the onset of LH synthesis by the pituitary and the expression of the LH receptor by the Leydig cells, suggesting that initial testosterone synthesis may be independent of gonadotropin stimulation $[14,15]$.

The HPG axis is auto-regulated via a negative feedback mechanism. This regulatory mechanism is thought to be the last component of the HPG axis to develop [15]. As gonadotropin hormones from the pituitary and steroid hormones from the gonads reach threshold levels in the circulation, GnRH secretion from the hypothalamus will decrease. In turn the expression of GnRH receptor and LH and FSH secretion will 
be down regulated at the pituitary level [1]. A similar mechanism exists at the level of the Leydig cell. When exposure to LH is prolonged or highly concentrated, the Leydig cell will compensate in a number of ways, including internalizing and degrading the luteinizing hormone receptor (LHR)-LH complex, effectively preventing the cell from responding to LH stimulation [16], by decreasing the rate of transcription of the LHR gene and by increasing the rate at which LHR mRNA is degraded [17]. 


\subsection{Leydig Cell Development and Differentiated Function}

Leydig cells reside in the interstitial space between the seminiferous tubules, closely associated with the vasculature of the testes because of their function as hormonesecreting endocrine cells [18]. During gestation, after the testis has differentiated into the specialized compartments of the testicular cords and interstitium, testicular mesenchymal stem cells differentiate into fetal Leydig cells $[15,19,20]$. This fetal population of Leydig cells express enzymes involved in steroidogenesis, have the machinery necessary for hormone secretion and produce androgens required for fetal masculinization $[15,19]$. In addition to androgen, fetal Leydig cells also produce the peptide hormone insulin-like peptide 3 (INSL3), which also plays a role male sexual development as a mediator of testicular descent [21]. Interestingly, fetal Leydig cells are not the precursors for the adult Leydig cells and will eventually undergo involution after the male genitalia have developed [15]; adult Leydig cells originate from stem cells present in the testes after birth [20].

The postnatal development of Leydig cells is characterized by undifferentiated mesenchymal stem cells progressing from a multipotent stem cell to a Leydig cell progenitor to an immature Leydig cell and finally differentiating into an adult Leydig cell (Reviewed in [20, 22]). The initial differentiation of mesenchymal stem cells into Leydig cell progenitors occurs in the rat between postnatal days 10 and 28 [20,23]. Leydig cell progenitors produce proteins that are exclusive to Leydig cells and are essential for steroid biosynthesis. The smooth endoplasmic reticulum (SER) contains the enzymes necessary for steroidogenesis including, $3 \beta$-hydroxysteroid dehydrogenase (3 $\beta$-HSD), cytochrome P450 17 $\alpha$-hydroxylase/C $17-20$ lyase (CYP17) and 17-ketosteroid 


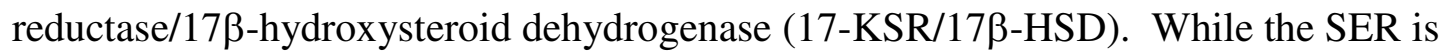
virtually absent in Leydig cell progenitors, they still possess some $3 \beta$-HSD activity and are capable of producing androgens (Reviewed in [20]). This may be due a mitochondrial source of steroidogenic enzymes during this stage of Leydig cell development [20]. While Leydig cell progenitors do express receptors for androgen, estrogen and insulin-like growth factor-1 (IGF-1), they only express the extracellular domain of the LHR and are therefore insensitive to LH stimulation [20].

Because of the lack of the intracellular domain of the LHR, other factors are implicated in the development and differentiation of Leydig cell progenitors into immature Leydig cells [20]. IGF-1 stimulates proliferation of mesenchymal stem cells, Leydig cell progenitors and immature Leydig cells. The surrounding Sertoli cells and testicular macrophages secrete proteins and cytokines that stimulate proliferation and differentiation of Leydig cells [20]. IGF-1 appears to play a role in Leydig cell maturation, as igf- 1 knockout mice possessed reduced numbers of Leydig cells, attributable to an aberration in differentiation and proliferation of Leydig cell progenitors. These igf-1 -/- mice also exhibited reduced testosterone levels, and reduced expression of several enzymes involved in steroidogenesis, including steroidogenic acute regulatory protein (StAR), CYP11A1 and CYP17A1 [24].

Leydig cell progenitors differentiate into immature Leydig cells between postnatal day 28 and 56 in the rat [20,23]. Immature Leydig cells have a well-developed SER and exhibit a greater amount of $3 \beta-\mathrm{HSD}$ activity than Leydig cell progenitors. They also contain numerous cytoplasmic lipid droplets, thought to be the primary source of 
cholesterol for steroidogenesis. Immature Leydig cells divide once before differentiating into adult Leydig cells [20, 22].

At the onset of puberty, approximately postnatal day 56 in the rat, immature Leydig cells differentiate to create the adult population of Leydig cells. Adult Leydig cells are larger and rarely proliferate. Rather the Leydig cell population is maintained at a relatively steady state, with Leydig cell death being balanced out by Leydig cell replenishment from stem cell populations within the testes [22]. The primary function of this population of Leydig cells is to respond to LH stimulation by producing testosterone to initiate spermatogenesis. Adult Leydig cells, therefore, express a greater amount of functional LHR. Additionally, the lipid content of this population of Leydig cells is markedly lower than that of their immature predecessors. These cells instead derive cholesterol necessary for steroidogenesis from serum lipoproteins or synthesize it de novo $[20,22,25]$. Though the timing of postnatal Leydig cell differentiation has been most fully characterized in the rat, a similar progression is thought to be present in the human and other species.

Steroidogenesis by the adult Leydig cell is characterized by a series of enzymatic reactions that catalyze the conversion of cholesterol into testosterone. Acquisition of cholesterol by the Leydig cell is achieved either via low-density lipoprotein (LDL) and high-density lipoprotein (HDL) receptors or synthesized de novo. Subsequently, it is transferred to the inner mitochondrial membrane under the regulation of StAR. Cholesterol is then converted to pregnenolone by CYP11A1. Pregnenolone is exported to the SER where it is converted to progesterone by $3 \beta-\mathrm{HSD}$. Then, progesterone is 
converted to $17(\mathrm{OH})$-progesterone and further to androstenedione by the dual function enzyme CYP17. Androstenedione is then converted to testosterone by $17 \beta-\operatorname{HSD}[1,26]$.

Testosterone travels to peripheral tissues via the blood stream and exerts its effects through the androgen receptor (AR). At the level of the testes, testosterone regulates spermatogenesis, Sertoli cell function and can exert an autocrine effect on the Leydig cell through the AR. Peripheral biological effects of testosterone include regulation of metabolic processes, male secondary sex characteristics and its own production through the negative feedback mechanism present in the HPG axis $[1,27]$.

Testosterone can be further converted to estrogen by the enzyme cytochrome P450 aromatase (CYP19). The Leydig cells are the primary source of testicular estrogen, though CYP19 is also present Sertoli and germ cells. Further, CYP19 has been detected in many peripheral tissues including adipose, liver, brain, kidney and skeletal muscle [26]. Testicular estrogen has been shown to regulate fluid transport within the male reproductive tract to effectively concentrate sperm before it enters into the epididymis. In male estrogen receptor- $\alpha(\mathrm{ER} \alpha)$ knockout mice, fluid reabsorption was impaired, resulting in infertility as the mice progressed in age [28]. Further, testicular estrogen participates in negative feedback regulation at the level of the hypothalamus and pituitary $[1]$.

In addition to estrogen, testosterone can also be converted to dihydrotestosterone (DHT) in the Leydig cells by the enzyme 5 $\alpha$-reductase [26]. DHT plays a role in negative feedback regulation of the HPG axis and is crucial for the masculinization of the male reproductive tract, including the development of the urethra, prostate and external genitalia [29]. 


\subsection{Testicular Descent}

Testicular descent is a critical process in mammalian male sexual development and is completed in humans and horses before birth; while in rodents, descent is completed postnatally $[8,30-33]$. Though the timing of events differs between species, the process of testicular descent is essentially the same. The testes migrate from high in the abdomen, adjacent to the kidneys, to the extra-abdominal location in the scrotum. The extra-abdominal position allows the testes to be maintained at a temperature $2-8^{\circ} \mathrm{C}$ lower than that of the body cavity $[4,5]$. This lower temperature is essential for maintaining spermatogenesis, fertility and gonadal function [4]. In several mammals including elephants, hyraxes, edentates, such as anteaters and armadillos, insectivores, such as sloths, and cetaceans, such as whales, the testes remain in the abdomen, without consequence to their reproductive capability. This is theoretically due to an inherently lower core body temperature, or the presence of alternative cooling mechanisms [34].

Testicular descent can be delineated into two phases, termed the transabdominal and inguinoscrotal phases. During the first or transabdominal phase, testes migrate from the level of the kidneys to the inguinal ring. This is achieved by concurrent regression of the cranial suspensory ligament (CSL) and development of the gubernaculum, the ultimate result of which is the testes moving to the level of the inguinal ring [2].

In the female, the development of the CSL and the regression of the gubernaculum keep the ovaries adjacent to the kidney; while in the male, CSL regression is essential to allow the gubernaculum to draw the testes downward [2]. The regression of the CSL is an androgen-dependent process, as evidenced by the persistence of the CSL and the testes remaining high in the abdominal cavity in both androgen-insensitive mice 
that possess a loss-of-function mutation of the AR and in normal rats that were fetally exposed to an AR antagonist $[35,36]$. The gubernaculum is attached firmly to both the testes and the area near the inguinal ring and the outgrowth and subsequent regression of the gubernaculum pulls the testes down toward the inguinal ring [37]. This process is regulated by INSL3, a peptide hormone produced by the Leydig cells of the testes. When INSL3 binds to its receptor on gubernacular cells, the proliferation and differentiation of the gubernaculum ensues, ultimately resulting in the anchoring of the testes at the inguinal ring [2, 38-40].

During the second or inguinoscrotal phase, the scrotum is hollowed out by the process vaginalis, creating a space for the incoming testes and the gubernaculum moves through the inguinal ring, drawing the testes into the scrotum $[2,7,41]$. The movement of the testes through the inguinal ring is driven, in part, by the shrinking of the gubernaculum, pulling the testes into the scrotum and in part by mounting intraabdominal pressure, pushing the testes through the inguinal ring $[7,33]$. The increase in intra-abdominal pressure is thought to stem from an increase in the size of the viscera, fetal respiratory efforts, and abdominal wall contraction [37]. The inguinoscrotal phase is mediated by testosterone as evidenced by the presence of the AR in gubernacular cells and the fact that the gubernaculum does not migrate beyond the inguinal region in gonadotropin-deficient and androgen-resistant animals [7, 42, 43]. 


\subsection{Cryptorchidism}

Cryptorchidism, or the failure of one or both of the testes to descend into the scrotum is a common developmental abnormality, affecting $2-8 \%$ of human male neonates and stallions [6]. Interestingly, many congenital cryptorchid cases have been shown to correct themselves within the first few months after birth, so the prevalence of this condition is reduced to $1-2 \%$ in boys between 3 and 12 months of age [7, 8]. This disorder has been shown to have a detrimental effect on fertility due to the maintenance of the testes at the higher temperature associated with the body cavity, compared to the relatively lower temperature in the scrotum [8]. Infertility is thought to stem from a degeneration of both steroidogenesis and germ cell production, each of which begin to show signs of deterioration within the first 6 months after birth in cryptorchid boys [7].

In addition to the impairment of fertility associated with this disorder, the risk of developing testicular cancer has been suggested to increase by about 5 to 10 -fold in the cryptorchid individual [7]. Interestingly, cryptorchidism has been reportedly associated with only $5 \%$ of testicular cancer cases, with bilaterally cryptorchid individuals running a greater risk of developing testicular malignancy than unilaterally cryptorchid individuals (Reviewed in $[4,7,8]$ ). Germ cell degeneration within the cryptorchid testes is thought to be the cause of this increased risk as developing spermatids in the testes are the most susceptible to heat and will either die or develop into spermatozoa with damaged DNA, potentially contributing to the development of a testicular malignancy [4].

Though a singular cause of cryptorchidism has not been identified, several potential causes and risk factors have been investigated. Cryptorchidism can occur as a single abnormality in healthy individuals or as a counterpart to other disorders such as 
abnormal midline differentiation, renal and urinary tract abnormalities, hypospadias, and malformations of the central nervous system [8]. Furthermore, in utero exposure to phthalate monoesters and persistent organochorlides has been linked to cryptorchidism $[8,33]$. Studies on the heritability of cryptorchidism have indicated that a child having a cryptorchid brother is more likely to also be cryptorchid than a child with a cryptorchid father, highlighting potential significance of the in utero environment [33]. Additionally, monogenetic causes of cryptorchidism have been investigated and though some cryptorchid cases may be attributed to an alteration in a given gene, those mutations do not account for the greater part of cryptorchid cases [33]. Collectively, these data suggest that there is no singular cause of cryptorchidism, but that the root of this disorder is as distinct as the individuals in which it occurs.

Treatment options vary with location of the testes and species. In humans, the testicles have reached their extra-abdominal location in the scrotum at the time of birth. Treatment options include orchidopexy, a surgical procedure in which the retained testis or testes are manually descended and fixed in the scrotum, or hormone therapy with hCG or GnRH, which has had marginal success, with about $10-20 \%$ of boys experiencing full testicular descent [7]. Correction of the cryptorchid phenotype, either manually or hormonally, can rescue fertility. For example, adult men with bilaterally cryptorchid testes are azoospermic, but after orchidopexy $28 \%$ of cases display a normal sperm count [8], though it seems that timely surgical intervention optimizes the chance for a full recovery of spermatogenic abilities, as degeneration of germ cells occurs within 6-12 months after parturition [7]. In stallions, the most common treatment of cryptorchidism is castration, which can be an invasive procedure depending upon the location of the 
testes. Hormone therapies have not been thoroughly investigated in horses. Treatment of cryptorchid stallions with hCG resulted in increased testosterone production by these individuals, though it did not have effect on the location of the testes [44]. 


\subsection{Luteinizing Hormone and Chorionic Gonadotropin}

LH is a heterodimeric peptide hormone composed of a common gonadotropin $\alpha$ subunit and an LH-specific $\beta$-subunit [45]. Similar to GnRH secretion from the hypothalamus, $\mathrm{LH}$ is secreted from the anterior pituitary in a pulsatile fashion, with pulses occurring every 3-6 hours [46]. In the male, LH stimulates testosterone synthesis by testicular Leydig cells in addition to regulating its own production as part of the negative feedback system present in the HPG axis.

In rodents, initial testosterone production is gonadotropin-independent as steroidogenesis begins before the onset of LH secretion in these models [14]. Once LH is present, however, there is a significant increase in LHR expression and testosterone production by the Leydig cells [15]. In contrast, chorionic gonadotropin is thought to stimulate fetal steroidogenesis in humans [14].

Chorionic gonadotropin (CG) is a glycoprotein hormone produced by the placenta during gestation to maintain pregnancy in only humans and horses [47, 48]. CG is composed of a common gonadotropin $\alpha$-subunit and a $\beta$-subunit that is about $80 \%$ homologous with the LH $\beta$-subunit [49] though CG has a greater molecular weight and is more heavily glycosylated than LH. More importantly, the receptor for CG is also the LHR, though CG binds this receptor with a relatively higher affinity than LH and has a longer half life in circulation [45, 47]. Despite the higher affinity for the LHR, CG is capable of eliciting effects equivalent to that of LH through this receptor. Further, human $\mathrm{CG}(\mathrm{hCG})$ is more easily purified from the placenta than $\mathrm{LH}$ is from the pituitary and is a commonly used as an LH analog for research purposes [17]. In the human, the main gonadotropic stimulus in utero is thought to be hCG as synthesis begins early in gestation 
and reaches a maximum in weeks 11-14; this is also the time when the testosterone content of the testes is at a maximum [14].

The most well characterized mechanism by which LH induces steroidogenesis by the Leydig cell is through the LHR-associated cyclic adenosine monophosphate/protein kinase-A (cAMP/PKA) signaling cascade. The LHR is a 7-transmembrane domain Gprotein coupled receptor (GPCR), located on the plasma membrane of the Leydig cell. When LH binds the extracellular domain of the LHR, the intracellular portion of the receptor undergoes a conformational change, activating a stimulatory G-protein $\left(G_{s}\right)$, which in turn activates the enzyme adenylyl cyclase. This enzyme catalyzes the conversion of ATP into cAMP, which in turn activates cAMP-dependent protein kinaseA (PKA) $[1,50]$. PKA then phosphorylates target proteins involved in testosterone production, such as the transcription factor SF-1, which then activates the transcription of steroidogenic enzymes, such as StAR protein $[51,52]$.

Though the LHR is undoubtedly associated with the cAMP/PKA pathway, several other pathways and factors have been shown to regulate steroidogenesis in response to LH. LHR and subsequent cAMP/PKA activation has been shown to activate the epidermal growth factor receptor (EGFR) and the associated mitogen-activated protein kinase (MAPK) pathway in MLTC-1 mouse Leydig cells. The transactivation of the EGFR by this mechanism was necessary for gonadotropin-induced steroidogenesis in this Leydig cell line [53]. The LHR has also been shown to activate the phopholipase C (PLC) pathway in the mouse fibroblast L cell line stably transfected with the murine LHR [54]. The down stream effector of PLC, protein kinase C (PKC) has been indirectly implicated in regulating LH-stimulated steroidogenesis as the presence of phorbol esters, 
which stimulate PKC activation, stimulated testosterone production in porcine Leydig cells $[52,55]$.

The transcription factor Nur77, discussed in detail later in this review, has been shown to regulate the promoters of several enzymes involved in steroidogenesis including CYP17 and 3 $\beta$-HSD [56, 57]. Inhibiting PKC in K28 Leydig cells and treating with $\mathrm{LH}$ abrogated the response to $\mathrm{LH}$ as evidenced by the $76 \%$ decrease in Nur77 mRNA compared with LH induction alone [58]. The phosphatidylinositol 3/protein kinase B (PI3K/PKB) pathway has also been implicated as an effector of LHR activation, as inhibition of this pathway abated the LH-dependent increase in Nur77 by $70 \%$ [58]. 


\subsection{Insulin-like Peptide 3}

Insulin-like peptide 3 (INSL3), a critical mediator of testicular descent, is a peptide hormone produced by the Leydig cells of the testes [31]. During fetal life, INSL3 is produced by the fetal Leydig cells and is essential for the completion of the transabdominal phase of testicular descent. In postnatal life, INSL3 levels increase significantly during puberty and INSL3 acts as a germ cell survival factor in both males and females [3, 59-61].

The necessity of INSL3 in the transabdominal phase of testicular descent has been demonstrated by transgenic insl3 knockout mice, in which all males were infertile and bilaterally cryptorchid, with the testes located high in the abdomen due to the failure of gubernacular development $[2,41]$. Female AR and insl3 knockout mice mirror the phenotype of the wild-type female [41]. In addition, when INSL3 is overexpressed in pancreatic beta cells of insl 3 knockout mice, testicular descent is restored in the male and in the female, the ovaries descend to an extra abdominal location [41]. The essential nature of INSL3 in the development of the gubernaculum and therefore the process of testicular descent suggests that a mutation in the insl3 gene or in that of its receptor may contribute to cryptorchidism. However, the occurrence of insl3 mutations in patients with alterations in testis descent is reportedly low, between 1.4-2.2\% [62, 63]. Further, the cumulative prevalence of mutations in the INSL3 receptor in cryptorchid individuals is only $2.9 \%$ [64].

INSL3 is also expressed in ovarian thecal and luteal cells and is thought to play a role in germ cell maturation. In cultured preovulatory follicles, treatment with INSL3 induced meiotic progression of arrested oocytes [3]. Further, female insl3 knockout mice 
exhibit impaired fertility and an elongated estrous cycle, though reproductive tract morphology and embryonic implantation were normal, indicating that INSL3 may help regulate the estrous cycle [38]. These results are not consistently observed; Zimmerman et al. (1999) found that insl3 female knockout mice not only exhibit a normal estrous cycle but also are capable of reproducing, without any apparent abnormalities noted in the offspring.

The receptor for INSL3, the leucine-rich repeat-containing G-protein-coupled receptor 8 (LGR8), is located on the membrane of gubernacular cells [65]. Mice in which the LGR8 gene has been deleted are phenotypically similar to insl3 knockout mice, in that the testes are located high in the abdomen, adjacent to the kidneys, due to the lack of gubernacular development in these animals [40]. These data highlight the essential nature of the INSL3/LGR8 ligand-receptor system in mediating the transabdominal phase of testicular descent. In gubernacular cells, cAMP levels have been shown to significantly increase in response to INSL3, implicating the cAMP/PKA signaling pathway in facilitating the growth and regression of the gubernaculum during the first phase of testicular descent [65].

LGR8 has also been detected in the germ cells of the testes and ovary, indicative of the continued and paracrine effects of INSL3 into adult life as a germ cell survival factor $[3,60]$. Interestingly, it has been shown that treatment of cultured preovulatory follicles with INSL3 led to a decrease in intra-oocyte cAMP levels, which allowed those oocytes to resume meiosis. Further, the inhibitory $\mathrm{G}_{\mathrm{i}}$ protein was implicated in this decrease in cAMP as concurrent treatment with a $G_{i}$ protein inhibitor impaired the ability of INSL3 to induce meiotic progression of oocytes [3]. 
Previous research in our lab has indicated that there is a lower abundance of INSL3 protein present in the retained as opposed to descended testis in unilaterally cryptorchid horses as determined by western blotting (Peterson et al., unpublished data). These results were congruent with those of Klonisch et al. (2003), who compared INSL3 levels between bilaterally cryptorchid horses and horses where both testicles were descended. The discrepancy in INSL3 production by the testes of unilaterally cryptorchid horses was of particular interest because two different levels of this hormone were present in the same tissue in the same animal and led us to investigate the factors that regulate the production of INSL3 by the Leydig cells of the testes. 


\subsection{INSL3 Regulation}

Several hormone cues, signal transduction components and transcription factors have been identified as having a role in mediating INSL3 production. Included in this regulatory milieu are $\mathrm{LH} / \mathrm{CG}$, testosterone, estradiol, the second messenger cAMP and the nuclear receptors SF-1 and Nur77. Though the individual effect of these regulatory components has been investigated in part, the comprehensive network of signals that ultimately regulates INSL3 production has yet to be fully defined.

LH/CG has been heavily implicated as a regulator of INSL3 production. For example, hCG has been shown to increase ovarian insl3 mRNA abundance when administered by injection to female rats [3]. Additionally, the second messenger cAMP, which is classically associated with the LHR has been shown to increase insl3 mRNA abundance in the MA-10 cell line [66]. Further evidence to suggest that luteinizing hormone may stimulate INSL3 production comes from transgenic mouse models. In transgenic hpg mice that lack a functioning HPG axis, insl3 mRNA levels are significantly lower than their wild-type counterparts but when supplemented with hCG, wild-type levels of insl3 are restored. LHR knockout mice are bilaterally cryptorchid, infertile and exhibit significantly lower abundance of insl3 mRNA than their wild-type counterparts $[67,68]$. Testosterone replacement therapy successfully restores gubernacular development and testicular descent in these animals [67, 68], though interestingly, did not increase insl3 mRNA abundance back to wild-type levels [68]. In the MA-10 Leydig cell line, testosterone has been shown to induce INSL3 production through the actions of the AR [69] and estradiol has an inhibitory effect on INSL3 production which can be abrogated by the actions of testosterone [70]. 
Steroidogenic factor 1 (SF-1), a prominent transcription factor involved in sexual development expressed in the hypothalamus and anterior pituitary gland, plays an essential role in the development of the HPG axis [9]. SF-1 has also been detected in Leydig and Sertoli cells, thecal and granulosa cells and adrenocortical cells [71]. Further SF-1 has been shown to bind to and transactivate the insl3 promoter in MA-10 Leydig cells. Experiments in which insl3 promoter reporter gene deletion constructs were transfected into MA-10 cells indicated that the -157 to $-53 \mathrm{bp}$ segment of the insl 3 promoter contains the putative response element for SF-1 and is sufficient for inducing the expression of the reporter gene in this context [72].

The transcription factor Nur77 is termed an orphan nuclear receptor, as it binds no known ligand. Nur77 is expressed in the testes and regulates the expression steroidogenic enzymes, including CYP17 and 3 $\beta$-HSD [56, 57]. Further, the expression of nur77 itself is induced in response to LH and cAMP in Leydig cells [56, 58]. In addition to the regulation of steroidogenic enzyme genes, Nur77 has been implicated in regulating the insl3 gene. When MA-10 cells were cotransfected with luciferase reporter vectors containing the $-1137 \mathrm{bp}$ to $+11 \mathrm{bp}$ region of the human insl3 promoter and increasing concentrations of Nur77 expression vectors, a dose-dependent increase in luciferase activity was observed, indicating that Nur77 is able to activate the human insl3 promoter. Experiments in which various 5' deletion constructs of the $-1137 \mathrm{bp}$ to $+11 \mathrm{bp}$ region of the human insl3 promoter and Nur77 expression vectors were cotransfected into MA-10 cells, indicated that the -322bp to -93bp segment of this promoter contains the Nur77 response element. Nur77 binding to this response element was confirmed by electromobility shift assay. Because Nur77 has been shown to increase in response to LH 
[58], and there is substantial evidence to suggest a similar response by insl3, it was hypothesized that Nur77 may be a downstream effector of the LHR and might be involved in regulating insl 3 production as well. MA-10 cells were cotransfected with Nur77 expression vectors and either a wild-type human insl3 reporter vector or one with a single mutation present in the Nur77 response element. These cells were then treated with cAMP, a second messenger known to be associated with the LHR. In this context, treatment with cAMP significantly increased the expression of the reporter gene in those cells that were transfected with the wild-type insl3 promoter. This effect of cAMP was completely abrogated in those cells that contained the vector with the mutated Nur77 response element. These data collectively indicated that cAMP is capable of activating the insl3 promoter through the actions of Nur77 [66].

The activity of Nur77 and subsequent ability of this transcription factor to bind to and activate a target promoter appears to be regulated by posttranslational modifications. In MA-10 cells transiently cotransfected with a human insl3 reporter vector and a $n u r 77$ expression vector, a significant increase in insl3 promoter activation was observed. In this context, Nur77 was found to require protein phosphatase activity to activate the insl3 promoter, as treatment with a protein phosphatase inhibitor completely abolished Nur77induced insl3 promoter activation, suggesting that Nur77 may require dephosphorylation to be active [73]. In adrenal medullar cells, phosphorylation of Nur77 at Ser340 and Ser 350 has been shown to decrease Nur77-DNA binding affinity and its ability to activate transcription, as these residues are located within the DNA-binding domain [74]. In other reporter vector experiments, adrenal cortical cells were cotransfected with a Nur77 response element reporter vector and an expression vector containing the catalytic 
subunit of PKA. There was a significant increase in the transcription of the reporter gene in the presence of the PKA expression vector. Additionally, cells transfected with the same Nur77 response element reporter vector and subsequently treated with forskolin, an adenylyl cyclase activator, also exhibited a significant induction of the Nur77-response element driven reporter gene. Furthermore, it appears that activation of the cAMP/PKA pathway promotes Nur77 binding to DNA in these adrenal cortical cells by inducing the dephosphorylation of Ser316. When adrenal cortical cells were cotransfected with the Nur77 response element reporter vector mentioned above, and an expression vector containing either the wild-type Nur77 or a Ser316Ala Nur77 mutant, which cannot be phosphorylated, the mutant form of Nur77 displayed a greater basal transcriptional activity than its wild-type counterpart. This effect was enhanced by the addition of PKA, implicating Nur77 as a down stream effector of the cAMP/PKA signal transduction pathway [75]. However, the mechanism of dephosphorylation, mainly the identity of the protein phosphatase that is required for the activation of Nur77 in this context and how it is linked to the cAMP/PKA pathway, remains to be elucidated. 


\subsection{MA-10 Cell Line:}

Cell models are useful and convenient tools for studying the function of a given cellular system or response. The goal of using such models is to accurately mimic in vivo function in a controlled setting, providing a practical alternative to whole animal studies. Cell culture methods of studying individual cell type function is particularly advantageous in that the environment in which the cells are maintained is easily controlled and manipulated, facilitating the assessment of a cellular response to a specified concentration of a treatment for an allotted amount of time.

Two widely used cell models are primary cell isolates and immortal cell lines. Though primary cell cultures are often regarded as bearing a greater similarity to in vivo function because of their immediate isolation and use from the tissue, they tend to be laborious to isolate, may contain other cell types native to the tissues from which they were isolated and are only capable of a limited number of cellular divisions. Immortal cell lines are homologous populations of cells that are theoretically capable of an infinite number of mitotic events. These types of cell lines are more stable, consistent and easier to maintain in culture than primary cells of the same type. The immortality of a cell line is either due to their derivation from a tumor, or their transformation with an immortalizing antigen [76]. The benefit and detriment of using a cell line lies with the fact that theoretically, a single cell type is present in each culture. While this feature allows for the assessment of the effects of a treatment on only the cell type of interest without the complication of other cell types and signals that are present in tissue samples, it removes an individual cell system from the potentially more biologically relevant in 
vivo context, where cells are regulated by cell-to-cell interactions, other cell types and other signals [76].

The inherent differences between cell lines and primary cultures lie with the fact that most cell lines are isolated from tumors, which confers their ability to continuously proliferate unlike primary cells. Immortal cell lines isolated from tumors can exhibit differential expression of any number of genes and that must be considered when using them as a model of normal in vivo function. For example, one of the hallmarks of an immortal cell line is the ability to continually divide. This is often due to the suppression of the p53 gene, which encodes a protein that can prevent a cell from entering the cell cycle if that cell's DNA is damaged [50]. Inactivation of this gene allows cells with mutated or damaged DNA to enter the cell cycle and proliferate. Indeed, mutations in the p53 gene are present in roughly half of all human cancers [50]. Therefore, within an immortal, tumor cell line, there may be any number of genes that harbor mutations not present in normal cells.

Primary Leydig cells are difficult to isolate because of the relatively low number of Leydig cells present in the testes. In culture, primary Leydig cells tend to lose differentiated function by becoming less responsive to gonadotropin stimulation and losing their capacity for steroidogenesis [77].

The MA-10 Leydig cell line was derived from the M5480 murine Leydig cell tumor [78]. These cells are gonadotropin responsive and produce INSL3. This cell line is a frequently utilized model of Leydig cell function, LH/CG activity, second messenger response, INSL3 production and steroidogenesis [77]. MA-10 cells are reported to 
produce progesterone instead of testosterone as a steroidogenic endpoint because of their apparent lack of cyp17 mRNA and activity [77].

MA-10 cells utilize several different means to regulate the availability of the LHR at the plasma membrane and hence, the ability of the cells to respond to LH/CG. One mechanism by which these cells control the response to gonadotropin stimulation is a rapid internalization of the LHR. This occurs more quickly in MA-10 cells than in primary Leydig cells for unknown reasons [77]. The fate of hCG-bound LHR has been studied in MA-10 cells. It has been shown that as the receptor-hormone complexes are internalized via receptor-mediated endocytosis and accumulate in lysosomes, hCG is dissociated from its receptor and degraded within the lysosome. In this study, it was not empirically determined whether the LHR is also degraded [79]. It still remains to be shown whether the LHR down-regulation is due to degradation of that receptor once it is internalized, or if the LHR is only temporarily sequestered away from the membrane. In all likelihood, it is a combination of these mechanisms that regulate the abundance of the LHR on the membrane of MA-10 cells. Further, both LH/CG and cAMP have been shown to decrease LHR mRNA abundance, though it is not clear whether this is due to a decrease in the transcription of the $l h r$ gene, an increase in the rate of LHR mRNA degradation, or a combination of both of these mechanisms [77, 80].

Over time, MA-10 cells have exhibited a decrease in both adherence to cell culture surfaces and proliferative capacity [81]. The reasons behind the noted decrease in attachment and proliferation have not been directly investigated, though it is speculated that these changes are due to a change in the manufacturing protocols and coatings of cell culture plasticware. This hypothesis is supported by the fact that cells maintained in 
liquid nitrogen since 1981 exhibit the same alterations and coating plasticware with a gelatin solution abrogates both proliferation and adherence issues [81]. MA-10 cells have also exhibited a decrease in LHR abundance from that of the parent cells from 5,000-20,000 receptors/cell (reviewed in [77]) to 600-1,000 receptors/cell. Because of this decrease, MA-10 cells were assessed for their ability to express a recombinant human LHR construct as part of an expression vector. These cells successfully expressed the human LHR on the membrane and were capable of binding hCG and responding with an increase in cAMP and progesterone production. The remaining endogenous receptors were deemed functionally capable of responding to gonadotropin stimulation as MA-10 cells transiently transfected with an empty expression vector responded to hCG treatment with a significant increase in both cAMP and progesterone production [81].

The MA-10 cell line is prevalent in the literature as a model of Leydig cell function despite the caveats detailed above. Because of the reported similarity to the whole testicular lysates in terms of expression of insl3 and nur77 [66], this cell line was deemed an appropriate model for the current work. 


\subsection{Summary}

The descent of the testicles into the scrotum is essential for normal male sexual development and continued fertility and testicular health throughout sexual maturity. The etiology of cryptorchidism is not well characterized, though differential expression of INSL3 in cryptorchid models illustrates the necessity of INSL3 in the process of descent and makes it a prime candidate for studying a potential cause of cryptorchidism. The regulation of INSL3 production, however, is not well understood. A comprehensive description of the factors that regulate the insl3 gene is paramount to understanding the process of testicular descent. As hormone therapies have been relatively unsuccessful in treating cryptorchidism, an enhanced understanding of the elements that regulate testicular descent may allow for the cause of each individual case of cryptorchidism to be more accurately defined, which may in turn enhance the selection of a more appropriate and useful hormone therapy for each individual case. Several factors have been implicated in INSL3 production and regulation, including $\mathrm{LH} / \mathrm{CG}$, the cAMP/PKA signal transduction pathway and the transcription factor Nur77. The following work utilizes these known factors and the MA-10 cell line to model and investigate the regulation of insl3 mRNA abundance in the Leydig cell. 


\section{List of References}

1. Porterfield, S.P.W., B.A., Endocrine Physiology. The Mosby Physiology Monograph Series. 2007, Philadelphia, PA: Mosby Elsevier.

2. Zimmermann, S.S., G.; Emmen, J.M.A.; Brinkmann, A.O.; Nayernia, K.; Holstein, A.F.; Engel, W.; Adham, I.M., Targeted Disruption of the Insl3 Gene Causes Bilateral Cryptorchidism. Molecular Endocrinology, 1999. 13: p. 681691.

3. Kawamura, K.K., J.; Sudo, S.; Chun, S.Y.; Pisarka, M.; Morita, H.; Toppari, J.; Fu, P.; Wade, J.D.; Bathgate, R.A.D.; Hsueh, A.J.W., Paracrine regulation of mammalian oocyte maturation and male germ cell survival Proceedings of the National Academy of Sciences, 2004. 101(19): p. 7323-7328.

4. Setchell, B.P., The effects of heat on the testes of mammals Animal Reproduction 2006. 3(2): p. 81-91.

5. Nelson, W.O., Mammalian Spermatogenesis: effect of experimental cryptorchidism in the rat and non-descent of the testes in man. Recent Progress in Hormone Research, 1961. 6: p. 29.

6. Chowdhury, A.K.S., E., Early changes in the germinal epithelium of rat testes following exposure to heat. Journal of Reproductive Fertility, 1970. 22(2): p. 205212.

7. Hutson, J.M.H., S.; Heyns, C.F., Anatomical and Functional Aspects of Testicular Descent and Cryptorchidism. Endocrine Reviews, 1997. 18(2): p. 259-280. 
8. Virtanen, H.E.B., R.; Cortes, D.; Jørgensen, N.; Rajpert-De Meyts, E.; Thorsson, A.V.; Thorup, J.; Main, K.M., Cryptochidism: classification, prevalence and long-term consequences. Acta Paediatrica, 2007. 96: p. 611-616.

9. Wilhelm, D.P., S.; Koopman, P., Sex Determination and Gonadal Development in Mammals. Physiology Reviews, 2007. 97: p. 1-28.

10. Swain, A.L.-B., R., Mammalian Sex Determination: A Molecular Drama. Genes and Development, 1999. 13: p. 755-767.

11. Viger, R.S.S., D.W.; Tremblay, J.J., New Insights into the Regulation of Mammalian Sex Determination and Male Sex Differentiation Vitamins and Hormones 2005. 70: p. 387-413.

12. Hannema, S.E.H., I.A., Regulation of Wolffian Duct Development. Hormone Research, 2007. 67: p. 142-151.

13. Wilson, J.D.G., F.W.; Griffin, J.E., The Hormonal Control of Sexual Development. Science, 1981. 211(4488): p. 1278-1284.

14. Huhtaniemi, I., Ontogeny of Luteinizing Hormone Action in the Male, in The Leydig Cell, A.H.H. Payne, M.P.; Russell, L.D., Editor. 1996, Cache River Press: Vienna, IL.

15. Huhtaniemi, I.P., L.J., Fetal Leydig Cells: Cellular Origin, Morphology, Life Span and Special Functional Features. Proceedings of the Society for Experimental Biology and Medicine, 1992. 201(2): p. 125-140.

16. Bernier, M.C., M.; Mombrial, C.F.; Saes, J.M., Processing of human choriogonadotropin and its receptors by culutred pig Leydig cells; role of cyclic 
AMP and protein synthesis. European Journal of Biochemistry, 1986. 155: p. 323330.

17. LeJeune, H.S., P.; Chuzel, F.; Langlois, D.; Saez, J.M., Time-course effects of human recombinant luteinizing hormone on porcine Leydig cell specific differentiated functions. Molecular and Cellular Endocrinology, 1998. 144: p. 5969.

18. Russell, L.D., Mammalian Leydig Cell Structure, in The Leydig Cell, A.H.H. Payne, M.P.; Russell, L.D., Editor. 1996, Cache River Press: Vienna, IL.

19. Pelliniemi, L.J.K., T.; Frojdman, K., The Cell Biology and Function of the Leydig Cell, in The Leydig Cell, A.H.H. Payne, M.P.; Russell, L.D., Editor. 1996, Cache River Press: Vienna, IL.

20. Ge, R.S.S., L.X.; Hardy, M.P., Pubertal Development of Leydig Cells, in The Leydig Cell, A.H.H. Payne, M.P.; Russell, L.D., Editor. 1996, Cache River Press: Vienna, IL.

21. Dong, L.J., S.A.; Finger, J.N.; Johnston, D.S.; Kopf, G.S.; Sottas, C.M.; Hardy, M.P.; Ge, R.S., Gene Expression During Development of Fetal and Adult Leydig Cells. Annals of the New York Academy of Sciences, 2007. 1120: p. 16-35.

22. LeJeune, H.H., R.; Saez, J.M., Origin, proliferation and differentiation of Leydig cells. Journal of Molecular Endocrinology, 1998. 20: p. 1-25.

23. Zirkin, B.R., Where do Adult Leydig Cells Come From? Biology of Reproduction, 2010. 82: p. 1019-1020. 
24. Hu, G.X.L., H.; Chen, G.R.; Chen, B.B.; Lian, Q.Q.; Hardy, D.O.; Zirkin, B.R.; Ge, R.S., Deletion of the IGF-1 Gene: Suppressive Effects on Adult Leydig Cell Development. Journal of Andrology, 2010. 31(4): p. 379-387.

25. Freeman, D.A.R., F.F.G., Regulation of Leydig Cell Cholesterol Transport in The Leydig Cell, A.H.H. Payne, M.P.; Russell, L.D., Editor. 1996, Cache River Press: Vienna,IL.

26. Payne, A.H.O.S., P.J., Structure, Function and Regulation of Steroidogenic Enzymes in the Leydig Cell, in The Leydig Cell, A.H.H. Payne, M.P.; Russell, L.D., Editor. 1996, Cache River Press: Vienna, IL.

27. Sundaram, K.K., N., Metabolism of Testosterone in Leydig Cells and Peripheral Tissues, in The Leydig Cell, A.H.H. Payne, M.P.; Russell, L.D., Editor. 1996, Cache River Press: Vienna, IL.

28. Hess, R.A., Estrogen in the adult male reproductive tract: A review. Reproductive Biology and Endocrinology, 2003. 1(52).

29. George, F.W.W., J.D., Sex Determination and Differentiation, in The Physiology of Reproduction E.N. Knobil, J., Editor. 1988, Raven Press: New York, NY.

30. Klonisch, T.F., P.A.; Hombach-Klonsich, S., Molecular and Genetic Regulation of Testis Descent and External Genitalia Development. Developmental Biology, 2004. 270: p. 1-18.

31. Adham, I.M.B., E.; Benahmed, M.; Engel, W., Cloning of a cDNA for a Novel Insulin-like Peptide of the Testicular Leydig Cells. The Journal of Biological Chemistry, 1993. 268(35): p. 26668-26672. 
32. Hughes, I.A.A., C.L., Factors Controlling Testis Descent. European Journal of Endoccrinology, 2008. 159: p. S75-S82.

33. Bay, K.M., K.M.; Toppari, J.; Skakkebaek, N.E., Testicular Descent: INSL3, Testosterone, genes and the intrauterine milieu. Nature Reviews Urology, 2011. 8: p. 187-196.

34. Setchell, B.P.B.W.G., Anatomy, vasculature and innervation of the male reproductive tract, in Knobil and Neill's Physiology of Reproduction, J.D. Neill, Editor. 2006, Elsevier: San Diego, USA. p. 771-825.

35. Van Der Schoot, P.E., W., Androgen-induced Prevention of the Outgrowth of the Cranial Gonadal Suspensory Ligaments in Fetal Rats. Journal of Andrology, 1992. 13(6): p. 534-542.

36. He, W.W.K., M.V.; Tindall, D.J., A frame-shift mutation in the androgen receptor gene causes complete androgen insensitivity in the testicular-feminized mouse. Nucleic Acids Research, 1991. 19(9): p. 2373-2378.

37. Heyns, C.F., The gubernaculum during testicular descent in the human fetus. Journal of Anatomy, 1987. 153: p. 93-112.

38. Nef, S.P., L.F., Cryptorchidism in mice mutant for insl3. Nature Genetics, 1999. 22: p. 295-299.

39. Feng, S.C., V.K.; Hwang, A.; Hardy, B.; Koh, C.J.; Bogatcheva, N.V.; Agoulnik, A.I., Mutation Analysis of INSL3 and GREAT/LGR8 Genes in Familial Cryptorchidism. Urology, 2004. 64: p. 1032-1036. 
40. Tomiyama, H.H., J.M.; Truong, A.; Agoulnik, A.I., Transabdominal testicular descent is disrupted in mice with deletion of insulin like factor 3 receptor Journal of Pediatric Surgery, 2003. 38: p. 1793-1798.

41. Adham, I.M.S., G.; Thamm, T.; Büllesbach, E.E.; Schwabe, C.; Paprotta, I.; Engel, W., The Overexpression of the Insl3 in Female Mice Causes Descent of the Ovaries. Molecular Endocrinology, 2002. 16(2): p. 244-252.

42. Emmen, J.M.A.M., A.; Adham, I.M.; Engel, W.; Grootegoed, J.A.; Brinkmann, A.O., Hormonal Control of Gubernaculum Development during Testis Descent: Gubernaculum Outgrowth in Vitro Requires Both Insulin-LIke Factor and Androgen. Endocrinology, 2000. 141(12): p. 4720-4727.

43. Hutson, J.M., Testicular Feminization: A Model for Testicular Descent in Mice and Men. Journal of Pediatric Surgery, 1986. 21(3): p. 195-198.

44. Brendemuehl, J.P., Effects of Repeated HCG Administration on Serum Testosterone and Testicular Descent in Prepubertal Thoroughbred Colts With Cryptorchid Testicles AAEP Proceedings, 2006. 52: p. 381-383.

45. Combarnous, Y., Molecular Basis of the Specificity of Binding of Glycoprotein Hormones to their Receptors. Endocrine Reviews, 1992 13: p. 670-691.

46. Senger, P.L., Pathways to Pregnancy and Parturition. Vol. Second Revised Edition. 2003, Pullman, WA: Current Conceptions, Inc.

47. Dufau, M.L., The Luteinizing Hormone Receptor, in The Leydig Cell, A.H.H. Payne, M.P.; Russell, L.D., Editor. 1996, Cache River Press: Vienna, IL. 
48. Allen, W.R.M., R.M., The Origin of the Equine Endometrial Cups. Production of PMSG by fetal trophoblast cells. Journal of Reproductive Fertility, 1972. 29: p. 313-316.

49. Talamantes, F.O., L., The Placenta as an Endocrine Organ: Polypeptides, in The Physiology of Reproduction, E.N. Knobil, J. , Editor. 1988, Raven Press Ltd: New York, NY.

50. Alberts, B.J., A.; Lewis, J.; Raff, M.; Roberts, K.; Walter, P., Molecular Biology of the Cell. 5 ed. 2008, New York, NY: Garland Science.

51. Stocco, D.M.W., X.; Jo, Y.; Manna, P.R., Multiple Signaling Pathways Regulating Steroidogenesis and Steroidogenic Acute Regulatory Protein Expression: More Complicated than We Thought. Molecular Endocrinology, 2005. 19(11): p. 2647-2659.

52. Leung, P.C.K.S., G.L., Intracellular Signaling in the Gonads. Endocrine Reviews, 1992. 13(3): p. 476-498.

53. Evaul, K.H., S.R., Cross-talk between G Protein-coupled and Epidermal Growth Factor Receptors Regulates Gonadotropin-mediatd Steroidogenesis in Leydig Cells. Journal of Biological Chemistry, 2008. 283(41): p. 27525-27533.

54. Gudermann, T.B., M.; Birnbaumer, L., Evidence for Dual Coupling of the Murine Luteinizing Hormone Receptor to Adenylyl Cyclase and Phosphoinositide Breakdown and Ca2+ Mobilization. The Journal of Biological Chemistry, 1992. 267(7): p. 4479-4488.

55. Kühn, B.G., T., The Luteinizng Hormone Receptor Activates Phospholipase C via Preferential Coupling to Gi2. Biochemistry, 1999. 38: p. 12490-12498. 
56. Martin, L.J.T., J.J., The Human 3 $\beta$-Hydroxysteroid Dehydrogenase/ $\Delta 5-\Delta 4$ Isomerase Type 2 Promoter Is a Novel Target for the Immediate Early Orphan Nuclear Receptor Nur77 in Steroidogenic Cells. Endocrinology, 2005. 146(2): p. 861-869.

57. Qamar, I.G., E.Y.; Kim, Y.; Song, C.H.; Lee, H.J.; Chun, S.Y.; Lee, K., Antisteroidogenic Factor ARR19 Inhibits Testicular Steroidogenesis through the Suppression of Nur77 Transactivation. The Journal of Biological Chemistry, 2010. 285(29): p. 22360-22369.

58. Song, K.H.P., J.I.; Lee, M.O.; Soh, J.; Lee, K.; Choi, H.S., LH Induces Orphan Nuclear Receptor Nur77 Gene Expression in Testicular Leydig Cells. Endocrinology, 2001. 142(12): p. 5116-5123.

59. Ferlin, A.G., A.; Rigon, F.; Caldogno, L.R.; Lenzi, A.; Foresta, C., Changes in Serum Insulin-Like Factor 3 during Normal Male Puberty. The Journal of Clinical Endocrinology and Metabolism, 2006. 91: p. 3426-3431.

60. Anand-Ivell, R.J.K.R., V.; Balvers, M.; Coiffec-Dorval, I.; Fritsch, M.; Bathgate, R.A.D.; Ivell, R., Expression of the Insulin-Like Peptide 3 (INSL3) HormoneReceptor (LGR8) System in the Testis. Biology of Reproduction, 2006. 74: p. 945953.

61. Bay, K.C., A.S.; Jørgensen, F.S.; Jørgensen, C.; LInd, A.M.; Skakkebæk, N.E.; Andersson, A.M., Insulin-Like Factor 3 Levels in Second-Trimester Amniotic Fluid. The Journal of Clinical Endocrinology and Metabolism, 2008. 93: p. 40484051. 
62. Ferlin, A.B., N.V.; Gianesello, L.; Pepe, A.; Vinanzi, C.; Agoulnik, A.I.; Foresta, C., Insulin-like factor 3 gene mutations in testicular dysgenesis syndrome: clinical and functional characterization. Molecular Human Reproduction, 2006. 12(6): p. 401-406.

63. Tomboc, M.L., P.A.; Mitwally, M.F.; Schneck, F.X.; Bellinger, M.; Witchel, S.F., Insulin-like 3/Relaxin-Like Factor Gene Mutations are Associated with Cryptorchidism The Journal of Clinical Endocrinology and Metabolism, 2000. 85(11): p. 4013-4018.

64. Foresta, C.Z., D.; Garolla, A.; Ferlin, A., Role of Hormones, Genes and Environment in Human Cryptorchidism. Endocrine Reviews, 2008. 29: p. 560580.

65. Kumagai, J.H., S.Y.; Matsumi, H.; Roh, J.S.; Fu, P.; Wade, J.D.; Bathgate, R.A.D.; Hsueh, A.J.W., INSL3/Leydig Insulin-like Peptide Activates the LGR8 Receptor Important in Testis Descent. The Journal of Biological Chemistry, 2002. 277(35): p. 31283-31286.

66. Robert, N.M.M., L.J.; Tremblay, J.J., The Orphan Nuclear Receptor NR4A1 Regulates Insulin-Like 3 Gene Transcription in Leydig Cells. Biology of Reproduction 2006. 74: p. 322-330.

67. Lei, Z.M.M., S.; Zou, W.; Xu, B.; Foltz, M.; Li, X.; Rao, C.V., Targeted Disruption of Luteinizing Hormone/Human Chorionic Gonadotropin Receptor Gene. Molecular Endocrinology, 2001. 15: p. 184-200. 
68. Yuan, F.P.L., D.X.; Rao, C.V.; Lei, Z.M., Cryptorchidism in LhrKO animals and the effect of testosterone-replacement therapy. Human Reproduction, 2006. 21(4): p. $936-942$.

69. Lague, E.T., J.J., Antagonistic Effects of Testosterone and the Endocrine Disruptor Mono-(2-Ethylhexyl) Phthalate on INSL3 Transcription in Leydig Cells Endocrinology, 2008. 149(9): p. 4688-4694.

70. Lague, E.T., J.J., Estradiol represses Insulin-like 3 expression and promoter activity in MA-10 Leydig cells. Toxicology, 2009. 258: p. 101-105.

71. Ingraham, H.A.L., D.S.; Ikeda, Y.; Luo, X.; Shen, W.H.: Nachtigal, M.W.; Abbud, R.; Nilson, J.H.; Parker, K.L., The nuclear receptor steroidogenic factor 1 acts at multiple levels of the reproductive axis. Genes and Development, 1994. 8: p. 2302-2312.

72. Zimmermann, S.S., A.; Buth, S.; Engel, W.; Adham, I.M., Transcription of the Leydig Insulin-Like Gene is Mediated by Steroidogenic Factor-1. Molecular Endocrinology, 1998. 12(5): p. 706-713.

73. Tremblay, J.J.R., N.M.; Lague, E., Nuclear Receptors, Testosterone, and Posttranslational Modifications in Human INSL3 Promoter Activity in Testicular Leydig Cells. Annals of the New York Academy of Sciences, 2009. 1160: p. 205212.

74. Hirata, Y.K., K.: Chen, H.C.; Milbrandt, J.; Guroff, G., The Phosphorylation and DNA Binding of the DNA-binding Domain of the Orphan Nuclear Receptor NGFI-B. The Journal of Biological Chemistry, 1993. 268(33): p. 24808-24812. 
75. Maira, M.M., C.; Batsché, E.; Gauthier, Y.; Drouin, J., Dimer-Specific

Potentiation of NGFI-B (Nur77) Transcriptional Activity by the Protein Kinase A Pathway and AF-1 Dependent Coactivator Recruitment. Molecular and Cellular Biology, 2003. 23(3): p. 763-766.

76. Freshney, R.I., Culture of Animal Cells. 4 ed. 2000, New York, NY: John Wiley and Sons, Inc.

77. Hoelscher, S.R.A., M., Immortalized Leydig cell lines as models for studying Leydig cell physiology, in The Leydig Cell, A.H.H. Payne, M.P.; Russell, L.D., Editor. 1996, Cache River Press: Vienna, IL. p. 523-534.

78. Ascoli, M., Characterization of several clonal lines of cultured Leydig tumor cells: gonadotropin receptors and steroidogenic responses. Endocrinology, 1981. 108: p. 88-95.

79. Ascoli, M., Lysosomal Accumulation of the Hormone-Receptor Complex during Receptor-mediated Endocytosis of Human Choriogonadotropin. The Journal of Cell Biology, 1984. 99: p. 1242-1250.

80. Wang, H.S., D.L.; Ascoli, M., Lutropin/Choriogonadotropin Down-regulates Its Receptor by Both Receptor-mediated Endocytosis and a cAMP-dependent Reduction in Receptor mRNA. The Journal of Biological Chemistry, 1991. 266(2): p. $780-785$.

81. Hirakawa, T.G., C.; Ascoli, M., MA-10 Cells Transfected with the Human Lutropin/Choriogonadotropin Receptor (hLHR): A Novel Experimental Paradigm to Study the Functional Properties of the hLHR. Endocrinology, 2002. 143(4): p. 1026-1035. 


\section{CHAPTER 2}

\section{The MA-10 Cell Line as a Model of insl3 Regulation and Leydig Cell Function}

\subsection{Introduction}

Insulin-like peptide 3 (INSL3), a peptide hormone produced by the Leydig cells of the testes, is a critical mediator of testicular descent. Male insl3 knockout mice are sterile and bilaterally cryptorchid [1] but when insl3 is overexpressed in the pancreatic $\beta$ cells of these mice, normal testicular descent is restored in the male and in the female, the ovaries descend to an extraabdominal location [2]. Though the central role of INSL3 in normal sexual development is appreciated, the factors that regulate INSL3 production have yet to be comprehensively defined.

The primary and most well known function of the Leydig cell is to produce testosterone in response to luteinizing hormone ( $\mathrm{LH})$ binding the G-protein coupled $\mathrm{LH}$ receptor (LHR) and activating the cyclic adenosine monophosphate/protein kinase A (cAMP/PKA) signal transduction pathway. Several other signal transduction pathways have been shown to be associated with the LHR, including the protein kinase B (PKB), mitogen activated protein kinase (MAPK) and the protein kinase $\mathrm{C}$ (PKC) pathways [35]. The LHR-linked cAMP/ PKA pathway may also regulate the production of INSL3 by the Leydig cell as cAMP has been shown to increase insl3 mRNA abundance in the MA10 Leydig cell line [6]. In transgenic hpg mice that lack a functioning hypothalamicpituitary-gonadal axis, insl3 mRNA levels are significantly lower than their wild-type counterparts but, when supplemented with hCG, wild-type levels of insl3 are restored [7].

The orphan nuclear receptor, Nur77, is a transcription factor that regulates the insl3 promoter and the promoters of several genes involved in steroidogenesis, including 


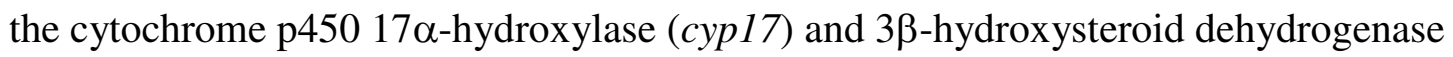
$(3 \beta$-hsd) promoters [8]. Nur77 has been shown to bind to its response element and activate the transcription of a reporter gene when the $-1137 \mathrm{bp}$ to $+11 \mathrm{bp}$ region of the human insl3 promoter is transfected into MA-10 Leydig cells as part of a reporter gene construct in addition to a Nur77 expression vector [6, 9]. Additionally, when MA-10 cells were transfected with either a wild-type Nur77 response element reporter vector or a mutated construct and treated with cAMP, there was a significant induction of the reporter gene only in those cells containing the wild-type vector. In this context, it seems that cAMP activates the insl3 promoter through the actions of Nur77 [6]. Further, the expression of nur77 itself is induced by LH in Leydig cells and the cAMP/PKA pathway promotes binding of Nur77 to DNA in adrenal cortical cells $[10,11]$. These results indicate that LH working through the cAMP/PKA pathway and the transcription factor Nur77 may be the mechanism by which INSL3 is produced by the Leydig cell, though this relationship has never been shown directly.

Recent studies in the MA-10 Leydig cell line indicate that treatment with estradiol results in a decrease in insl3 mRNA abundance, with those effects being abrogated by testosterone [12]. Treatment of MA-10 cells with testosterone concentrations ranging from 1.5 to $1500 \mathrm{nM}$ for $36 \mathrm{~h}$, resulted in an increase in insl 3 mRNA abundance. Further, when the same $-1137 \mathrm{bp}$ to $+11 \mathrm{bp}$ segment of the human insl3 promoter is transfected into MA-10 cells, as part of a reporter gene construct, transcription of the reporter gene is activated in response to $15 \mathrm{nM}$ testosterone treatment for $36 \mathrm{~h}$. The addition of an androgen receptor (AR) antagonist abrogated the effects of testosterone on both insl3 
mRNA abundance and insl3 promoter activation, suggesting that testosterone is able to exert an autocrine effect on the Leydig cell and regulate insl3 through the AR [13].

The MA-10 Leydig cell line was isolated from a murine Leydig cell tumor and retained many of the characteristics of normal Leydig cells such as LHR expression, INSL3 production and increased steroidogenesis in response to cAMP and LH/CG stimulation [14]. This cell line is currently accepted as a model of steroidogenesis and Leydig cell function, despite the fact that these cells are reported to lack CYP17 activity and therefore produce progesterone instead of testosterone as a steroidogenic endpoint [15]. Over time, MA-10 cells have exhibited a decrease in both adherence to cell culture surfaces and proliferative capacity, each of which can be addressed by coating plasticware with a gelatin solution [16]. They have also exhibited a decrease in LHR abundance from that of the parent cells from 5,000-20,000 receptors/cell (reviewed in [15]) to 600-1,000 receptors/cell, though the remaining receptors are functionally capable of responding to gonadotropin stimulation [16].

Despite these inherent limitations, the MA-10 cell line was chosen as a model for the current work because they coexpress insl3 and nur77 [6] and are functionally capable of responding to gondadotropin stimulation [16]. The overall objective of this research was to further characterize the factors that regulate insl3 production in the Leydig cell, by determining whether LH/CG induces insl3 production, confirming the effect of LH/CG on nur77 and then deciphering which signal transduction pathway(s) may be involved in regulating both insl3 and nur77 mRNA abundance. Additionally, the mRNA abundance of the steroidogenic enzymes cyp17 and $3 \beta$-hsd was measured in response to LH/CG and the second messenger cAMP, to determine the functional status of the MA-10 cell as a 
steroidogenic model. MA-10 cells were also supplemented with exogenous testosterone to assess the autocrine effects of testosterone on both insl3 and nur77 abundance. 


\subsection{Materials and Methods}

All reagents were purchased from Sigma Aldrich, unless otherwise indicated.

\section{Cell Culture}

MA-10 cells were generously provided by Dr. Mario Ascoli (University of Iowa, IA). Prior to plating, $25 \mathrm{~cm}^{2}$ cell culture flasks (Corning) were incubated with $0.1 \%$ gelatin solution $\left(0.5 \mathrm{~g}\right.$ DIFCO bactogelatin, $500 \mathrm{ml} \mathrm{Ca}{ }^{2+} / \mathrm{Mg}^{2+}$-free PBS) covering the growth area of the flask for 45 minutes at room temperature. The gelatin solution was aspirated before plating. Cells were maintained at $37^{\circ} \mathrm{C}$ in $5 \% \mathrm{CO}_{2}$ in DMEM F12 growth medium (pH 7.7) supplemented with 20mM HEPES, $15 \%$ horse serum (Invitrogen), $1 \%$ penicillin/streptomycin and $1 \%$ amphotericin B. Within each experiment, cells were cultured with horse serum from the same lot.

Human CG (Cell Sciences), 8-bromo cAMP, $(\mathrm{Bu})_{2}$-cAMP and testosterone were included in media at concentrations indicated in figure legends. For signal transduction pathway inhibitor experiments, MA-10 cells were pre-treated with one of the following inhibitors for 3 hours: 10 $\mu \mathrm{M}$ H 89-dihydrochloride (H89; PKA inhibitor), 10nM wortmannin (WORT; PKB inhibitor), $10 \mu \mathrm{g} / \mathrm{ml}$ pseudohypericin (PH; PKC inhibitor) or 50 $\mu$ M PD90859 (PD; MAPK inhibitor)(Santa Cruz Biotechnology). The pre-treatment growth media was then replaced with growth media containing either 0 or $100 \mathrm{ng} / \mathrm{ml} \mathrm{hCG}$ and the inhibitor for an additional 1 or 3 hours before RNA extraction, as indicated in Figure 2A/B 


\section{RNA Extraction and Reverse Transcription}

Cells were released from flasks through incubation with $0.5 \mathrm{X}$ trypsin/EDTA solution and subsequently washed in $5 \mathrm{ml}$ media by centrifugation. Total RNA was extracted from the resulting cell pellet using the RNeasy ${ }^{\circledR}$ Mini Kit (Qiagen). The RNA concentration of each sample was determined by spectrophotometry. First strand cDNA

was synthesized from $1 \mu \mathrm{g}$ RNA using the iScript ${ }^{\mathrm{TM}}$ Select cDNA Synthesis Kit (BioRad), with either oligo dT or random primers.

\section{Quantitative Real Time Polymerase Chain Reaction}

Quantitative polymerase chain reaction (qPCR) was used to quantify target gene mRNA abundance. Gene-specific primers (Table 1) were used to amplify target genes in cDNA samples using an Applied Biosystems 7500 Fast Real-Time PCR System (1 cycle at $95^{\circ} \mathrm{C}$ for 20 seconds, 50 cycles at $95^{\circ} \mathrm{C}$ for 3 seconds, and 1 cycle at $60^{\circ} \mathrm{C}$ for 30 seconds) with Fast SYBR Green Master Mix (Applied Biosystems, Foster City, CA). The specificity of each primer set was verified by dissociation curve. To further validate the insl3 primers, the qPCR product was gel purified using the Qiagen Qiaquick ${ }^{\circledR}$ Gel Extraction Kit per the manufacturer's protocol and sequenced by Sequetech (Mountain View, CA). Target mRNA abundance values were obtained using the $2^{-\Delta \Delta C t}$ equation using the abundance of TATA binding protein (TBP) mRNA as an internal control to correct for reverse transcription efficiency. 


\section{Statistical Analysis}

All qPCR data were analyzed using the general linear model in Statistical Analysis Software (SAS Carey, NC), with all treatments being compared to the control. The abundance of target mRNA is reported as the mean $\pm \operatorname{SEM}(n=3)$. Means were considered significantly different at $P<0.05$.. 


\begin{tabular}{|c|c|c|c|c|}
\hline & & & \multicolumn{2}{|l|}{ Size } \\
\hline Mus & Sense & CCTCCTGGCTATGTCATTGCAACA & $85 b p$ & NM_013564.6 \\
\hline $\begin{array}{l}\text { musculus } \\
\text { insl3 }\end{array}$ & Antisense & CTGTGGTCCTTGCTTACTGCGAT & & \\
\hline Mus & Sense & AGACCTGTTGCTAGAGTCTGCCTT & $147 b p$ & NM_010444.2 \\
\hline $\begin{array}{c}\text { musculus } \\
\text { nur77 }\end{array}$ & Antisense & TCAATCCAATCACCAAAGCCACGG & & \\
\hline Mus & Sense & TGCTCATTCCACACAAGGCTAACA & $132 b p$ & NM_007809.3 \\
\hline $\begin{array}{c}\text { musculus } \\
\text { cyp17 }\end{array}$ & Antisense & TAAACCGATCTGGCTGGTCCCATT & & \\
\hline Mus & Sense & TCAGCCACCACCATCTCAGACTTT & $81 \mathrm{bp}$ & NM_008293.3 \\
\hline $\begin{array}{c}\text { musculus } \\
3 \beta \text {-hsdl }\end{array}$ & Antisense & AGCCGCTCAGTTCAGAATGTAGGA & & \\
\hline Mus & Sense & ACACTCAGTTACAGGTGGCAGCAT & $130 b p$ & NM_013684 \\
\hline $\begin{array}{c}\text { musculus } \\
\text { tbp }\end{array}$ & Antisense & CAAGTAGCAGCACAGAGCAAGCAA & & \\
\hline
\end{tabular}

Table 1: Gene specific primers for quantitative polymerase chain reaction. Accession numbers indicate the GenBank sequence that was referenced to design primers using IDT DNA Technologies PrimerQuest software. Primers were validated and chosen based upon their scores in both NetPrimer and Beacon Designer software programs. 


\subsection{Results}

Treatment with $100 \mathrm{ng} / \mathrm{ml}$ hCG did not have a significant effect on insl3 mRNA abundance at 1, 2, or 3 hours (Figure 1A). The ability of MA-10 cells to respond to gonadotropin stimulation was confirmed by measuring nur77 mRNA abundance in hCGtreated samples. There was a significant but transient increase in nur77 mRNA abundance at $1 \mathrm{~h}$ of treatment, while at 2 and $3 \mathrm{~h}$, nur 77 mRNA abundance was significantly lower than that of the control (Figure 1B).

To determine which signal transduction pathway the LHR uses to regulate insl3 and nur77 production by the Leydig cell, MA-10 cells were subjected to a 3 hour pretreatment period with inhibitors of four pathways that have been shown to be utilized by the LHR: cAMP/PKA, PI3K/PKB, PKC and MAPK signal transduction pathways. Following pre-treatment, the cells were treated with media containing the inhibitor with which the sample was pre-treated and 100ng/ml hCG for 1 and $3 \mathrm{~h}$. The abundance of insl3 mRNA was not increased in response to hCG alone. Inhibition of any one pathway did not affect insl3 mRNA levels, though there was a significant increase in insl3 mRNA abundance when the PI3K/PKB pathway was inhibited in the presence of hCG for $3 \mathrm{~h}$ (Figure 2A). The abundance of nur77 mRNA was significantly increased in response to hCG treatment for one hour as before, though this induction was not affected by the addition of any single pathway inhibitor (Figure 2B). The pre-treatment period alone did not affect insl3 or nur77 mRNA abundance (data not shown).

Though it has been shown that cAMP increases insl3 mRNA in the MA-10 cell line [6], inhibition of the cAMP/PKA pathway with or without hCG did not affect the abundance of insl3 mRNA in the MA-10 cell line (Figure 2A). Treatment with 8-bromo 
cAMP for 6 hours significantly decreased insl3 mRNA abundance, while $(\mathrm{Bu})_{2}$-cAMP did not affect insl3 mRNA abundance (Figure 3A), while both cAMP analogs significantly increased nur77 mRNA abundance after 6 hours of treatment (Figure 3B). Because cAMP is a second messenger and therefore may have an effect in a shorter time frame, cells were treated with $0.5 \mathrm{mM}(\mathrm{Bu})_{2}$-cAMP for $0.5,1,2$ and 4 hours. The abundance of insl3 mRNA was still unaffected, even at these shorter time points (Figure 4A), while nur77 mRNA abundance was significantly increased at all time points (Figure 4B).

To assess the status is the steroidogenic machinery of the MA-10 cell line, the abundance of $3 \beta$-hsd and cyp17 mRNA was quantified in response to hCG and cAMP. Neither $100 \mathrm{ng} / \mathrm{ml} \mathrm{hCG}$ or $0.5 \mathrm{mM}$ cAMP at any time point have any effect on $3 \beta$-hsd mRNA abundance (Figure 5A,C).

It has been shown that MA-10 cells do not express cyp17 mRNA and therefore do not convert progesterone to testosterone during steroidogenesis [15]. Contrary to these findings, cyp17 mRNA was not only present, but significantly increased in response to 100ng/ml hCG at 1, 2, and 3 hours and $0.5 \mathrm{mM}(\mathrm{Bu})_{2}$-cAMP at 2 and 4 hours (Figure 5B,D).

The ability of this cell line to respond to gonadotropin stimulation was confirmed by the significant increase in nur77 mRNA in response to hCG. Others have shown that testosterone increases insl3 mRNA in the MA-10 cell [13]. Because this cell line is purported to lack CYP17 activity and therefore produces progesterone instead of testosterone, the potential autocrine actions of testosterone on insl3 production would not be apparent in the MA-10 cell line. Therefore, MA-10 cells were supplemented with 
exogenous testosterone. While testosterone alone did not affect nur77 mRNA abundance, hCG alone significantly increased nur77 mRNA abundance at both 1 and 3 hours. Additionally, the combination of hCG and testosterone significantly increased nur77 mRNA abundance at both 1 and 3 hours (Figure 6A). In accordance with the initial treatment of MA-10 cells with hCG, insl3 mRNA abundance remained unchanged at all time points. Interestingly, treatment of MA-10 cells with $15 \mathrm{nM}$ testosterone did not affect insl3 mRNA abundance, nor did the combination of hCG and testosterone (Figure 6B). 

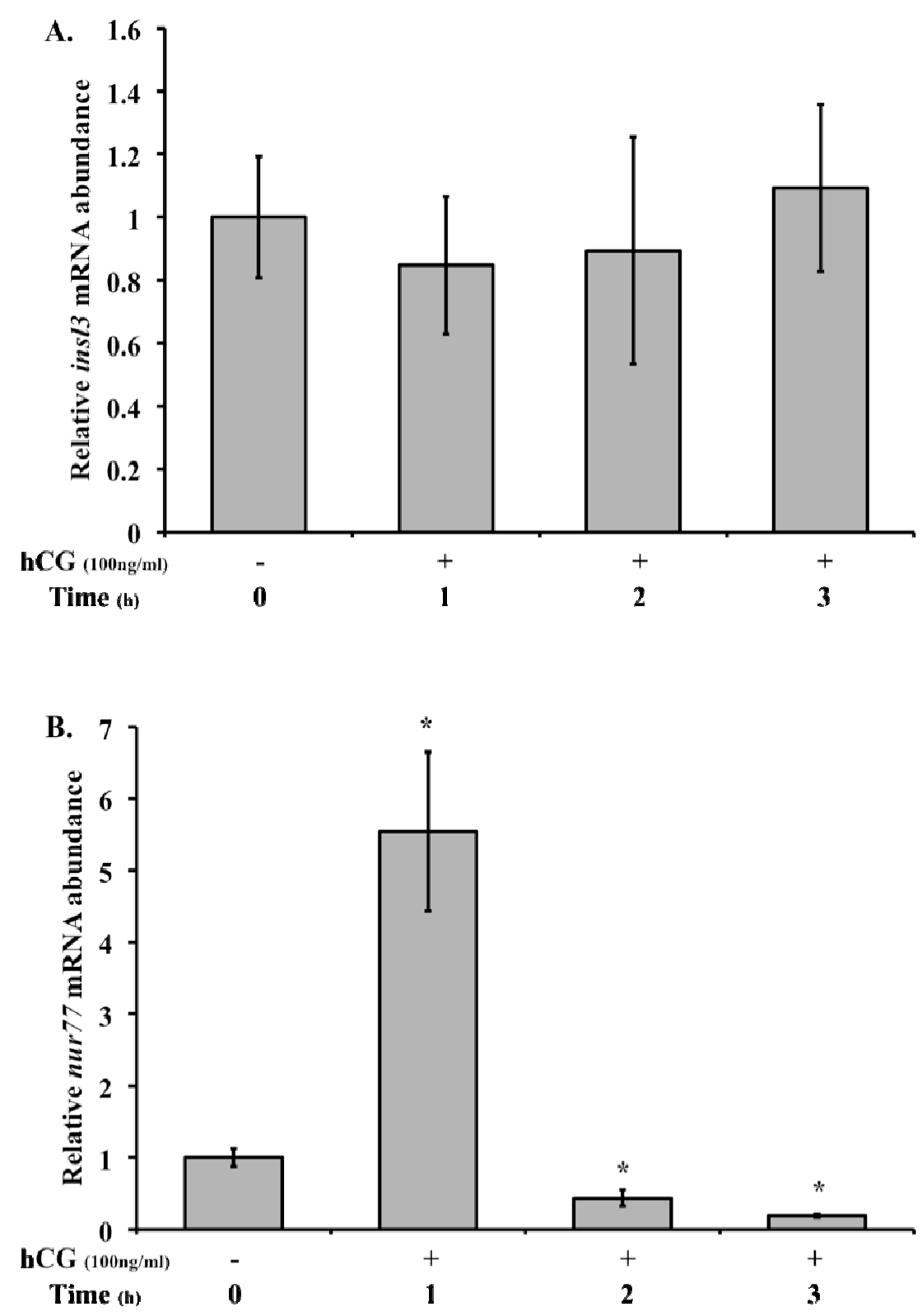

Figure 1: The effect of hCG on insl3 and nur77 mRNA abundance: Insl3 (A) and nur77 (B) mRNA abundance in MA-10 cells treated with $100 \mathrm{ng} / \mathrm{ml} \mathrm{hCG}$ for 1,2 and $3 \mathrm{~h}$. Values represent the mean \pm SEM $(\mathrm{n}=3)$; an asterisk indicates a statistically significant difference from the control $(P<0.05)$. 

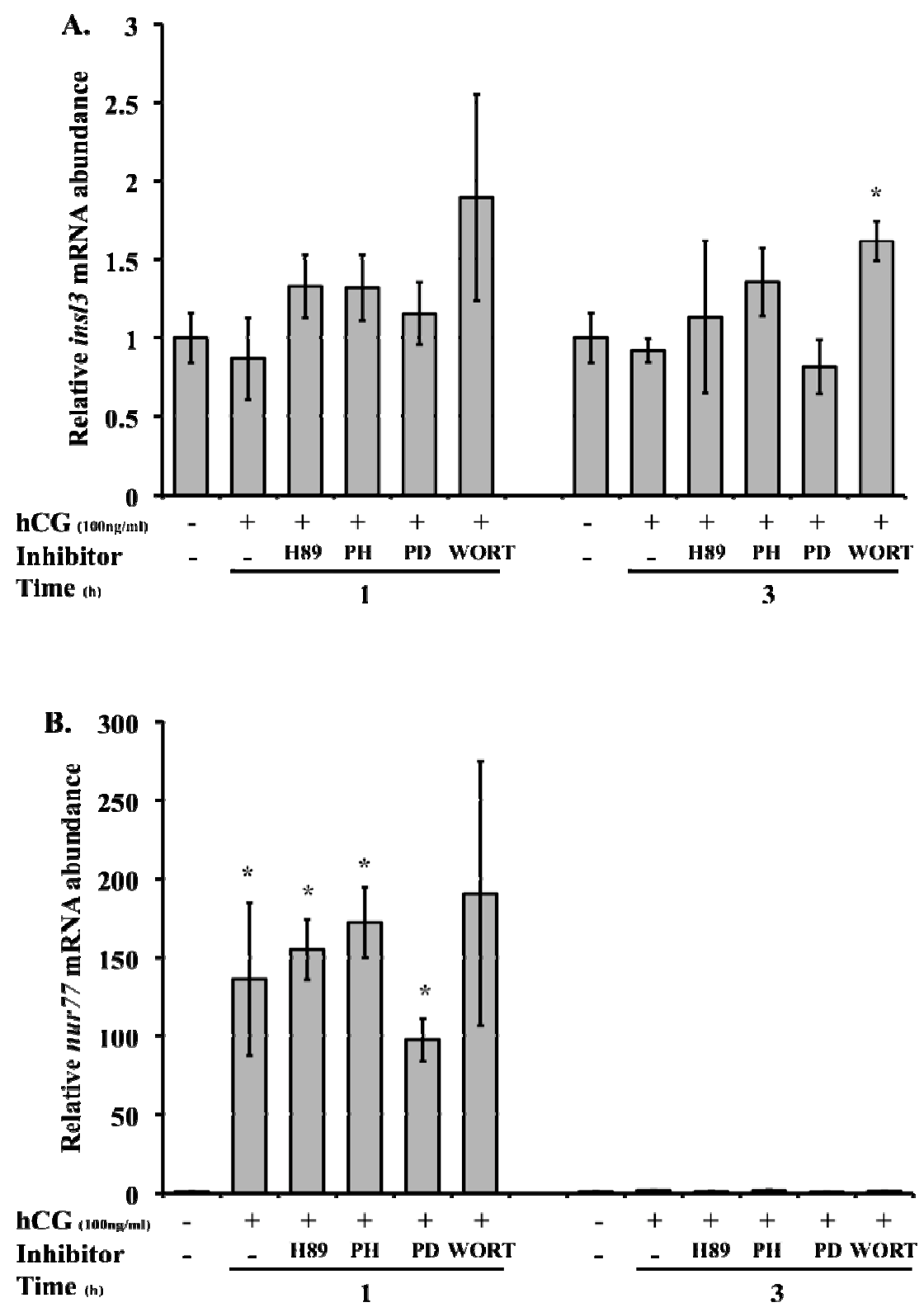

Figure 2: The effect of hCG and pathway inhibition on insl3 and nur77 mRNA abundance: Insl3 (A) and nur77 (B) mRNA abundance in MA-10 cells treated with 10 $\mu$ M H 89-dihydrochloride (H89; PKA inhibitor), 10nM wortmannin (WORT; PKB inhibitor), $10 \mu \mathrm{g} / \mathrm{ml}$ pseudohypericin (PH; PKC inhibitor) or 50 $\mu \mathrm{M}$ PD90859 (PD; MAPK inhibitor) and 100ng/ml hCG for 1 and $3 \mathrm{~h}$. Values represent the mean \pm SEM $(\mathrm{n}=3)$; an asterisk indicates a statistically significant difference from the control $(P<0.05)$. 

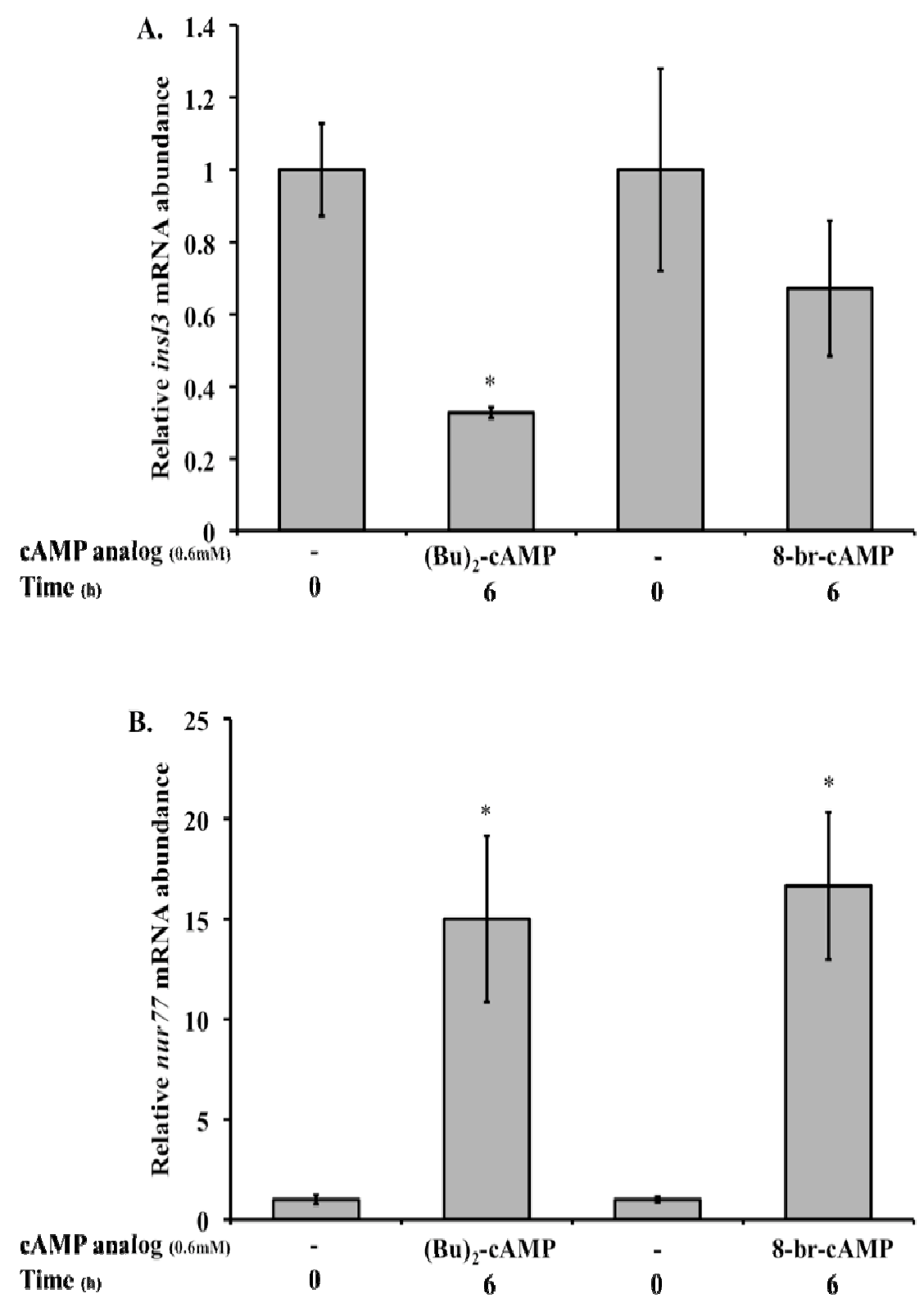

Figure 3: The effect of cAMP analogs on insl3 and nur77 mRNA abundance: Insl3 (A) and $n u r 77$ (B) mRNA abundance in MA-10 cells treated with $0.6 \mathrm{mM} 8$-bromo cAMP or $0.6 \mathrm{mM}(\mathrm{Bu})_{2}$-cAMP for 6 hours. Values represent the mean $\pm \operatorname{SEM~}(\mathrm{n}=3)$; an asterisk indicates a statistically significant difference from the control $(P<0.05)$. 

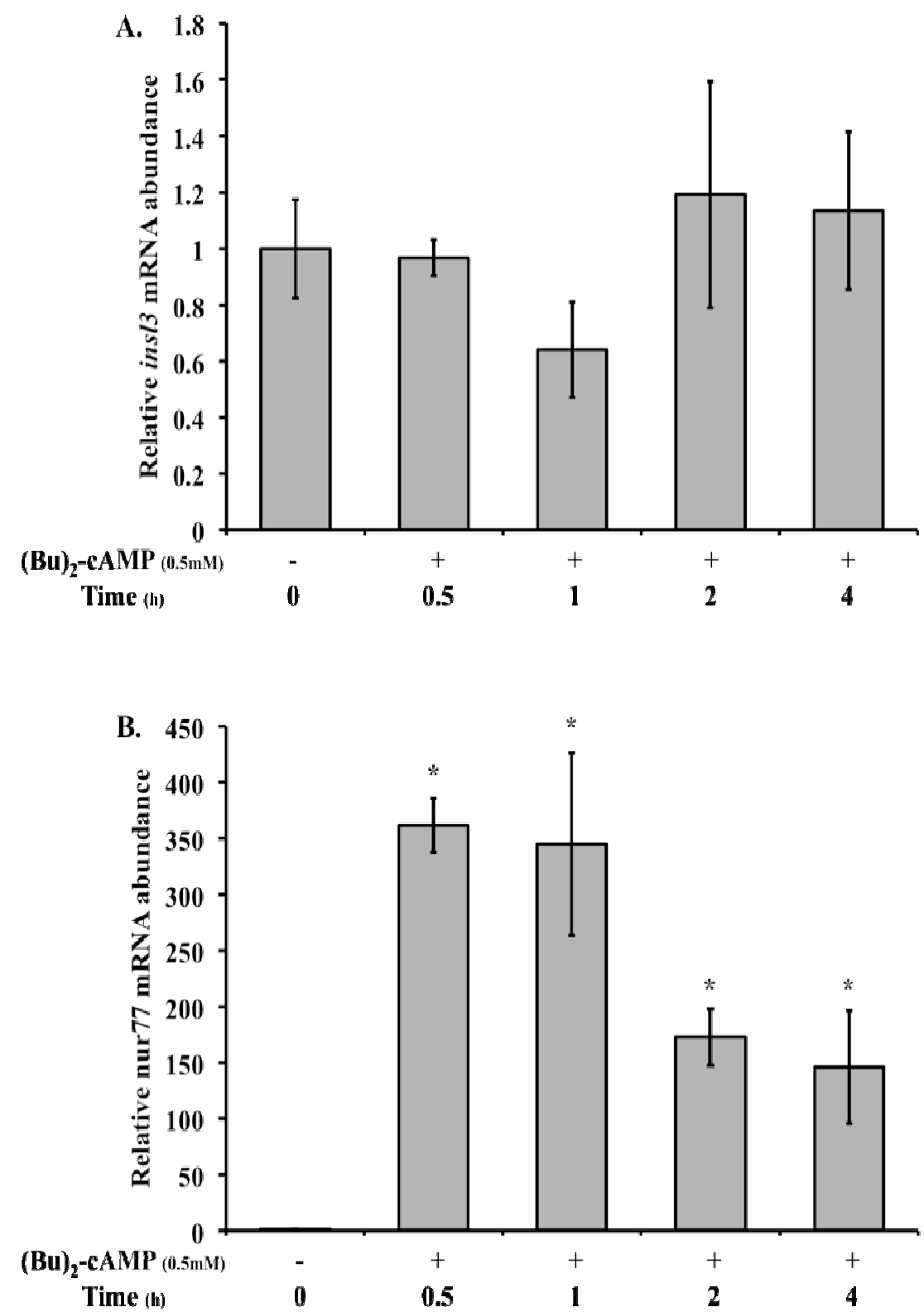

Figure 4: The effect of $(\mathrm{Bu})_{2}$-cAMP on insl3 and nur77 mRNA abundance at four different time points: Insl3 (A) and nur77 (B) mRNA abundance in MA-10 cells treated with $0.5 \mathrm{mM}(\mathrm{Bu})_{2}$-cAMP for $0.5,1,2$, and $4 \mathrm{~h}(\mathrm{C})$. Values represent the mean $\pm \mathrm{SEM}$ $(\mathrm{n}=3)$; an asterisk indicates a statistically significant difference from the control $(P<0.05)$. 

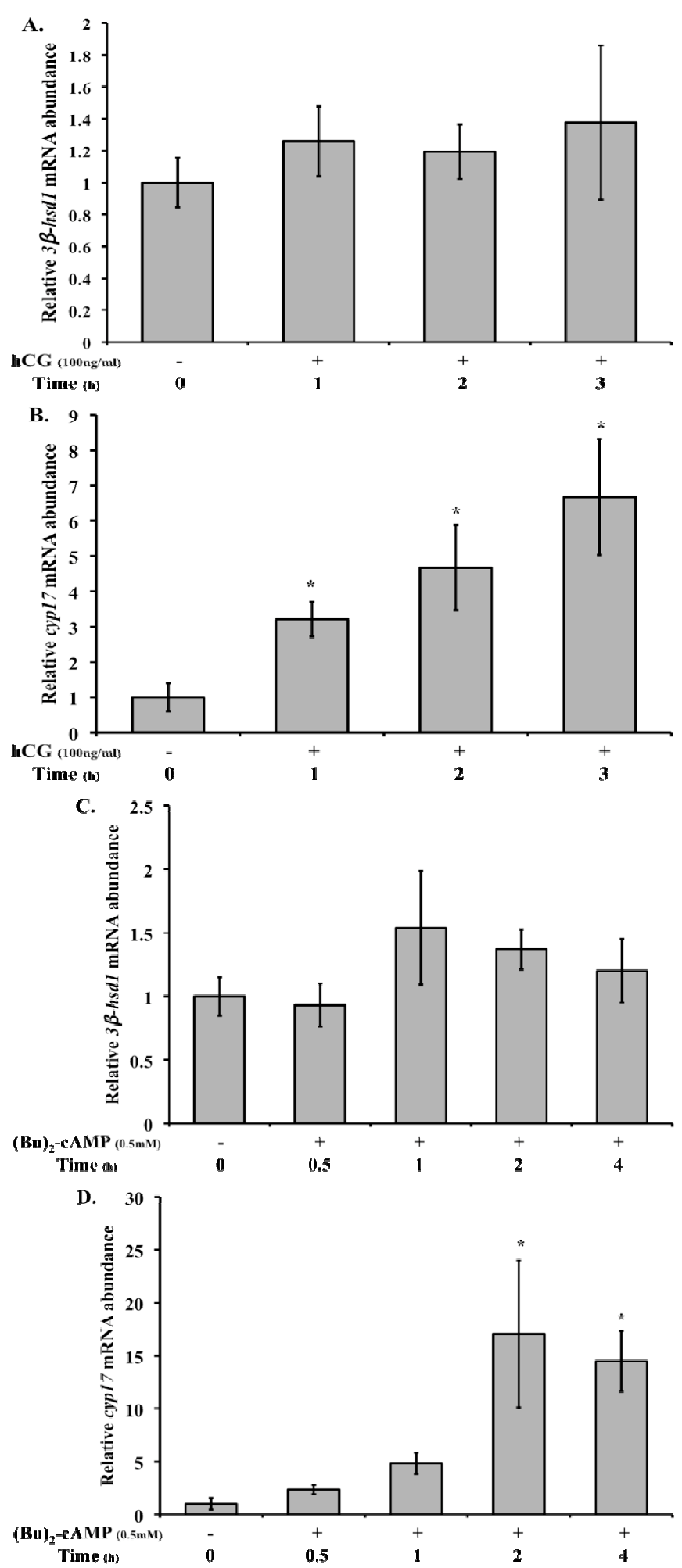

Figure 5: The effect of hCG and cAMP on $3 \beta$-hsd and cyp17 mRNA abundance: $3 \beta$ hsd and cyp 17 mRNA abundance in MA-10 cells treated with $100 \mathrm{ng} / \mathrm{ml}$ hCG for 1,2 and $3 \mathrm{~h}(\mathrm{~A}, \mathrm{C})$ or $0.5 \mathrm{mM}(\mathrm{Bu})_{2}$-cAMP for $0.5,1,2$ and $4 \mathrm{~h}(\mathrm{~B}, \mathrm{D})$. Values represent the mean \pm SEM $(n=3)$; an asterisk indicates a statistically significant difference from the control $(P<0.05)$. 

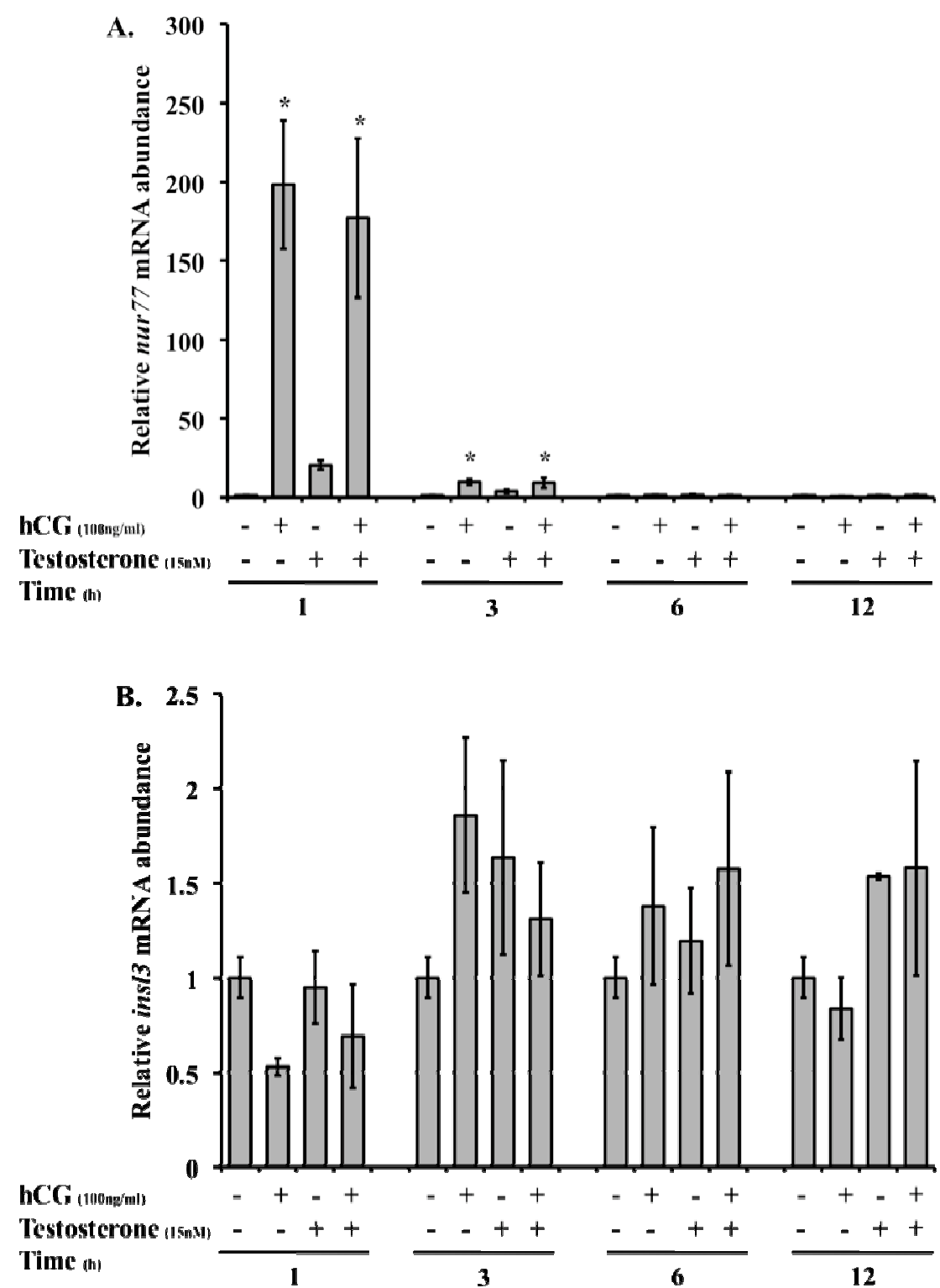

Figure 6: The effect of hCG and testosterone on insl3 and nur77 mRNA abundance: Insl3 (A) and nur77 (B) mRNA abundance in MA-10 cells treated with 100ng/ml hCG and $15 \mathrm{nM}$ testosterone in a $2 \times 2$ factorial design for 1 and $3 \mathrm{~h}$. Values represent the mean \pm SEM $(n=3)$; an asterisk indicates a statistically significant difference from the control $(P<0.05)$. 


\subsection{Discussion}

Though there was considerable evidence in the literature implicating $\mathrm{LH}$ as the stimulus of INSL3 production, treatment with hCG did not affect insl3 mRNA abundance in the MA-10 cell line. These data indicate either an inability of the MA-10 cell to respond to gonadotropin stimulation or that there is another means by which insl3 is regulated. The robust increase in nur77 mRNA abundance in response to hCG indicates that these cells are indeed capable of responding to gonadotropin stimulation, suggesting an alternative mechanism that regulates insl3 production in the Leydig cell.

Additional evidence to support an alternative stimulus of insl3 production comes from the observation that individual inhibition of the LHR-linked cAMP/PKA, PKC or MAPK pathways in the presence of hCG did not have an effect on insl3 mRNA levels at 1 or 3 hours. The exception is the significant increase in insl 3 mRNA abundance observed in the presence of hCG and wortmannin for $3 \mathrm{~h}$, indicative of hCG being capable of inducing insl3 after $3 \mathrm{~h}$, but only when the PI3K/PKB pathway is inhibited. Multiple pathways could be responsible for activating or repressing insl3 production. These data indicate that the PI3K/PKB pathway may have a suppressive effect on insl3. Individually, The cAMP/PKA, PKC or MAPK kinase pathways do not seem to play a role in insl3 regulation, though they may work in concert and with other pathways that were not included as a part of this work. Inhibition of multiple pathways at once may provide further insight into the combinatorial role of these pathways in insl3 production.

Though hCG treatment for one hour consistently and significantly increased nur77 mRNA abundance, the pathway through which hCG works to produce this effect remains unclear. The addition of any single pathway inhibitor did not affect the ability of 
hCG to induce nur77 production. As with insl3, these data indicate that there may be multiple pathways, potentially including some that were not included in this experiment, that regulate nur77 mRNA abundance in the Leydig cell. A similar experiment was conducted in the K28 Leydig cell line, where cells were treated for 1h with 200ng/ml LH and either 10uM H89 (PKA inhibitor), 100nM bisindolylmaleimide I (PKC inhibitor) or 10nM wortmannin (PKB inhibitor). Nur77 mRNA abundance was assessed by Northern blot. LH treatment alone significantly increased nur77 mRNA, concurrent with the results presented above. However, when PKA was inhibited in the presence of LH, the LH- mediated induction of Nur77 mRNA was decreased by $73 \%$. Further, inhibition of $\mathrm{PKC}$ and $\mathrm{PKB}$ in the presence of $\mathrm{LH}$ resulted in a $76 \%$ and $70 \%$ reduction in nur77 mRNA, respectively [10]. It is important to note that in the present work, the same PKA and PKB inhibitors were utilized at the same concentration, with divergent results from those in the literature. Though an effect of pathway inhibition was observed in the K28 Leydig cell line and not in the present work in the MA-10 cell line, what is consistent is the indication that multiple pathways regulate nur77 mRNA abundance in the Leydig cell.

Inhibition of the cAMP/PKA pathway did not affect insl3 or nur77 mRNA abundance. Similarly, treatment of MA-10 cells with cAMP analogs did not induce insl3; specifically, treatment with $0.5 \mathrm{mM}(\mathrm{Bu})_{2}$-cAMP for $4 \mathrm{~h}$ failed to increase insl3 mRNA abundance. These results are contrary to that of Robert et al. (2006), though the same cell line and experimental design was utilized. Interestingly, though both cAMP analogs at all time points significantly increased nur77 mRNA, inhibition of the cAMP/PKA pathway did not abrogate the hCG-induced increase in nur77 abundance. 
While the cAMP-mediated increase in nur77 mRNA implicates the cAMP/PKA pathway in nur77 regulation, the inhibition of that pathway does not corroborate those results, suggesting that the cAMP/PKA pathway may not be the only pathway involved in the hCG-regulation of nur77 mRNA abundance.

The abundance of $3 \beta$-hsd mRNA remained unchanged in the presence of hCG and cAMP. Though $3 \beta$-HSD activity, mRNA and protein abundance have been shown to increase in primary Leydig cell cultures in response to LH and cAMP, these effects were not realized until 24h of treatment [17], suggesting that the effects of hCG and cAMP on $3 \beta$-hsd mRNA abundance may not be observed until a later time point. Additionally, in primary Leydig cell cultures, $3 \beta$-hsd mRNA seems to be expressed at relatively high basal levels in the absence of either LH or cAMP [18].

Though it has been shown that MA-10 cells do not express cyp17 [15], the current data indicate otherwise. Not only do these cells express cyp17, but also it is inducible in the presence of hCG and cAMP. Though it was surprising to detect cyp 17 mRNA in MA-10 cells, the induction of cyp17 in the presence of both $\mathrm{hCG}$ and cAMP is consistent with previous work in primary mouse Leydig cells, which indicated that CYP17 enzyme activity was basically undetectable in the absence of LH or cAMP, but when cells were treated with LH or cAMP, there was a time-dependent increase in CYP17 activity over the course of 5-7 days [19-21]. The present data indicate that a similar time-dependent increase in cyp17 mRNA may be observed over a matter of hours.

It has been shown that treatment of MA-10 cells with testosterone significantly increases insl3 mRNA abundance after 36h [13]. In the present work, $12 \mathrm{~h}$ treatment of MA-10 cells with testosterone or the combination of hCG and testosterone did not affect 
insl3 mRNA abundance. Testosterone may still play a role in insl3 production through an autocrine action on the Leydig cell, though perhaps over a longer period of time. Treatment with hCG and the combination of hCG and testosterone significantly increased nur77 mRNA abundance at one and three hours. The primary stimulus for this increase seems to be hCG, as testosterone alone did not have an effect and hCG treatment alone resulted in an increase similar to that observed with the combination of $\mathrm{hCG}$ and testosterone.

The response of the MA-10 cell line to hCG is inconsistent relative to the magnitude of response exhibited by nur77 and the induction of nur77 at times greater than one hour. These inconsistencies between experiments may be due to the fact that it was not possible to maintain all cells for all experiments in serum from the same lot. Serum is a common requirement in cell culture media and provides growth and adhesion factors, minerals, lipids and hormones to the cells. Typically, these components are present in unknown concentrations and there is a high degree of variability between batches of serum. To negate these issues, some cell lines can be maintained in serum free media, which is formulated to contain all necessary factors in known concentrations for that cell line [22]. Another method of eliminating variability in cell response due to serum factors is to serum-starve the cells for a designated amount of time before applying treatment to remove the effects of the serum on the cells before assessing the cellular response to treatment. Though not presented here, all attempts to culture MA-10 cells without serum resulted in detachment and significant cell death, so serum starvation was not a viable protocol for these cells. To minimize the potential effects of serum in the present work, all individual experiments were conducted with serum from the same lot 
and though the serum lot may have differed between experiments, it never differed within experiments. Therefore, the inherent differences between serum lots may account for some variability between experiments.

The inter-experiment variability may also be due to the fact that fresh hCG was purchased for each experiment in an effort to correct for a potential decline in hormone activity due to prolonged storage in solution. The inconsistencies between experiments may be a manifestation of inherent differences in the hCG preparations used for each experiment. Therefore, the parameters of each experiment were as similar as possible, though they were not identical because of the inability to culture MA-10 cells in serumfree media and the requirement for fresh $\mathrm{hCG}$ for each experiment. 


\subsection{Conclusions and Implications}

Cell models, particularly primary cell isolates and immortalized cell lines, are widely used to assess cellular systems and individual cell function. Though primary cultures potentially bear greater similarity to cells in vivo, they can be laborious to isolate, difficult to maintain in culture, may contain other cell types and possess the inherent limitation of a finite number of cell divisions.

Immortalized cell lines are homologous populations of cells, easier to maintain in culture and theoretically capable of an infinite number of divisions. The immortality of these cells is due to either their tumorogenic lineage or transformation with an immortalizing antigen. The homology of a cell line allows for the assessment of the effects of a treatment on only the cell type of interest, without the complication of other cell types and signals that are present in tissue samples. This homology does, however remove an individual cell system from the potentially more biologically relevant in vivo context, where cells are regulated by cell-to-cell interactions, other cell types and other signals [22]. Further, using a tumorogenic cell line removes the model even further from

the natural context, as these cell lines can exhibit differential expression of any number of genes.

Prevalent in the literature as a tool for investigating steroidogenesis, LH/CG actions, INSL3 regulation and other Leydig cell functions, the MA-10 cell line is a widely accepted and utilized Leydig cell line isolated from a murine Leydig cell tumor. Comparison with other Leydig cell lines and primary cells has revealed that the MA-10 cell line most closely mimics in vivo Leydig cell expression of several key genes, including insl3, nur77 and $s f-1$ [6]. 
The shortcomings of the MA-10 cell line, such as the decrease in LHR abundance, proliferative capacity, adherence to cell culture surfaces and the alleged lack of a critical steroidogenic enzyme seem to be manageable issues. MA-10 cells are still functionally capable of responding to gonadotropin stimulation, plating on gelatin rescues proliferation and attachment problems and insl3 production is not dependent on the aforementioned steroidogenic enzyme. Therefore, in this context, the MA-10 cell line appeared to be useful model to study insl3 regulation.

Further experimentation with this cell line suggested otherwise. The results of this work conflict with previously published data in terms of the insl3 response to cAMP and the presence of cyp17 mRNA. Because of the detrimental effects of serum starving this cell line, eliminating serum as a contributing factor of inter-experiment variability is impractical. This poses a problem for assessing the response of the MA-10 cell line to hormone stimulation, because of the unknown factors present in serum that may enhance or abrogate a response by the cell to any additional treatment. The inconsistencies with previous work along with the inability to correct for the variability between experiments suggest that this cell line may no longer be a suitable model of Leydig cell function as it has been in previous years. 


\subsection{Reconciliation and Future investigations}

Though LH was implicated in the literature by numerous studies as a potential regulator of insl3 production by the Leydig cell, it was surprising that the current data indicated otherwise. This coupled with the discrepancy between these and published data regarding the cAMP-mediated increase in insl3 mRNA abundance may be accounted for by the numerous regulatory factors that have yet to be identified in this system. Though the current work does not necessarily provide direct empirical evidence to support the presence of other factors, it does indicate that there may be several other features of the insl3 production process that may warrant further investigation.

Though the MA-10 cell line has been shown to lack CYP17 mRNA and activity, the current work indicates that at the very least, cyp17 mRNA is present and inducible in the presence of hCG and cAMP. If this cell line has differentially expressed this enzyme over time and regained the ability to express CYP17, the expression of any number of other genes may have also changed. For example, it has been shown that Nur77 is a downstream effector of the cAMP/PKA pathway and must be dephosphorylated at several serine residues to allow and promote the binding of this transcription factor to the promoters that it regulates $[11,23,24]$. However, the specific mechanism by which this dephosphorylation is regulated and the identity of the protein phosphatase that modulates this activation of Nur77 remains to be identified. If the regain of cyp17 expression by the MA-10 cell line coincided with a loss in the ability to express the protein phosphatase responsible for activating Nur77, hCG and cAMP may not be able to induce an increase insl3 mRNA because of the lack of Nur77 activation. 
In addition to the possibility that the MA-10 cells exhibit a different expression pattern of an unknown number of genes than Leydig cells in vivo, the presence of a repressor that interacts with the insl3 promoter may account for lack of induction of insl3 in the presence of both cAMP and hCG. In this case, if the stimulus required to remove the repressor is not expressed by the MA-10 cell line, the repressor would continue to inhibit transcription and the mRNA abundance of insl 3 would not increase in response to cAMP or hCG. Though a repressor that specifically regulates insl 3 production has not been identified, inhibition of Nur77 action may also have an effect on insl3 mRNA abundance. The androgen receptor corepressor-19 $\mathrm{kDa}$ (ARR19) has been shown to inhibit the transactivation of Nur77 in MA-10 cells by interacting with Nur77 and thereby preventing Nur77 from binding to the coactivator steroid receptor coactivator (SRC-1). This was demonstrated by transfecting MA-10 cells with Nur77 response element-driven reporter vectors and Nur77 and ARR19 expression vectors. In this context, the presence of ARR19 resulted in the repression of Nur77 transactivation in a dose-dependent manner. Further, when MA-10 cells were cotransfected with CYP17, StAR and 3 $\beta$-HSD reporter constructs and Nur77 and ARR19 expression vectors, ARR19 inhibited Nur77induced promoter activity of each of the tested steroidogenic enzyme genes. ARR19 was further shown regulate Nur77 transactivation by physically interacting with this transcription factor and preventing Nur77 from binding SRC-1 [25].

The evidence indicating that Nur77 binds to and is capable of activating the insl3 promoter in the MA-10 cell line was obtained by cotransfecting cells with an insl3 promoter-driven reporter construct and a Nur77 expression vector [6]. In this context, Nur77 may be able activate the insl3 promoter only because Nur77 is over expressed and 
therefore may have the ability to overwhelm any repressors present in the MA-10 cells at that time. While these data provide a useful starting point for understanding the complex process of insl3 regulation, the use of a singular expression vector further removes the data from the biologically relevant in vivo context, where all regulatory factors would theoretically be present in natural amounts relative to one another. In order to accurately assess the factors that regulate insl3 production through transfection assays, expression vectors of all pertinent factors would need to be utilized, whether they be coactivators or repressive in nature. In the current work, the abundance of the factors that regulate insl3 mRNA abundance would only be determined by the cells themselves, as no exogenous expression vectors were utilized. It may be that because Nur77 was not overexpressed in this case, any repressors that were present could not be overwhelmed by the endogenous amounts of Nur77. Further, because only the abundance of nur77 mRNA was determined and not that of all other pertinent factors, whether or not those factors are produced by the MA-10 cell line remains to be determined.

These data and those of the current work indicate that there may be numerous layers of regulatory mechanisms at work in the Nur77-regulated production of insl3 by the MA-10 Leydig cell. Investigating the role of these factors in insl3 regulation in this cell line and in a primary Leydig cell line or in vivo would be critical to validating the MA-10 cell line as an appropriate Leydig cell model and gaining a more comprehensive understanding of the complex network of factors that control this system. 


\section{List of References}

1. Zimmermann, S.S., G.; Emmen, J.M.A.; Brinkmann, A.O.; Nayernia, K.; Holstein, A.F.; Engel, W.; Adham, I.M., Targeted Disruption of the Insl3 Gene Causes Bilateral Cryptorchidism. Molecular Endocrinology, 1999. 13: p. 681691.

2. Adham, I.M.S., G.; Thamm, T.; Büllesbach, E.E.; Schwabe, C.; Paprotta, I.; Engel, W., The Overexpression of the Insl3 in Female Mice Causes Descent of the Ovaries. Molecular Endocrinology, 2002. 16(2): p. 244-252.

3. Salvador, L.M.M., E.; Hales, D.B.; Miyamoto, E.; Yamamoto, H.; HunzickerDunn, M. , Acute Signaling by the LH Receptor Is Independent of Protein Kinase C Activation Endocrinology, 2002. 143(8): p. 2986-2994.

4. Evaul, K.H., S.R., Cross-talk between G Protein-coupled and Epidermal Growth Factor Receptors Regulates Gonadotropin-mediatd Steroidogenesis in Leydig Cells. Journal of Biological Chemistry, 2008. 283(41): p. 27525-27533.

5. Kühn, B.G., T., The Luteinizng Hormone Receptor Activates Phospholipase C via Preferential Coupling to Gi2. Biochemistry, 1999. 38: p. 12490-12498.

6. Robert, N.M.M., L.J.; Tremblay, J.J., The Orphan Nuclear Receptor NR4A1 Regulates Insulin-Like 3 Gene Transcription in Leydig Cells. Biology of Reproduction 2006. 74: p. 322-330.

7. Balvers, M.S., A.N.; Domagalski, R.; Hunt, N.; Kilic, E.; Mukhopadhyay, A.K.; Hanks, E.; Charlton H.M.; Ivell, R., Relaxin-Like Factor Expression as a Marker of Differentiation in the Mouse Testis and Ovary. Endocrinology, 1998. 139(6): p. 2960-2970. 
8. Martin, L.J.T., J.J., The Human 3 $\beta$-Hydroxysteroid Dehydrogenase/ $\Delta 5-\Delta 4$ Isomerase Type 2 Promoter Is a Novel Target for the Immediate Early Orphan Nuclear Receptor Nur77 in Steroidogenic Cells. Endocrinology, 2005. 146(2): p. 861-869.

9. Zimmermann, S.S., A.; Buth, S.; Engel, W.; Adham, I.M., Transcription of the Leydig Insulin-Like Gene is Mediated by Steroidogenic Factor-1. Molecular Endocrinology, 1998. 12(5): p. 706-713.

10. Song, K.H.P., J.I.; Lee, M.O.; Soh, J.; Lee, K.; Choi, H.S., LH Induces Orphan Nuclear Receptor Nur77 Gene Expression in Testicular Leydig Cells. Endocrinology, 2001. 142(12): p. 5116-5123.

11. Maira, M.M., C.; Batsché, E.; Gauthier, Y.; Drouin, J., Dimer-Specific Potentiation of NGFI-B (Nur77) Transcriptional Activity by the Protein Kinase A Pathway and AF-1 Dependent Coactivator Recruitment. Molecular and Cellular Biology, 2003. 23(3): p. 763-766.

12. Lague, E.T., J.J., Estradiol represses Insulin-like 3 expression and promoter activity in MA-10 Leydig cells. Toxicology, 2009. 258: p. 101-105.

13. Lague, E.T., J.J., Antagonistic Effects of Testosterone and the Endocrine Disruptor Mono-(2-Ethylhexyl) Phthalate on INSL3 Transcription in Leydig Cells Endocrinology, 2008. 149(9): p. 4688-4694.

14. Ascoli, M., Characterization of several clonal lines of cultured Leydig tumor cells: gonadotropin receptors and steroidogenic responses. Endocrinology, 1981. 108: p. 88-95. 
15. Hoelscher, S.R.A., M., Immortalized Leydig cell lines as models for studying Leydig cell physiology, in The Leydig Cell, A.H.H. Payne, M.P.; Russell, L.D., Editor. 1996, Cache River Press: Vienna, IL. p. 523-534.

16. Hirakawa, T.G., C.; Ascoli, M., MA-10 Cells Transfected with the Human Lutropin/Choriogonadotropin Receptor (hLHR): A Novel Experimental Paradigm to Study the Functional Properties of the hLHR. Endocrinology, 2002. 143(4): p. 1026-1035.

17. Keeney, D.S.M., J.I., Expression of testicular 3 beta-hydroxysteroid dehydrogenase/delta 5----4-isomerase: regulation by luteinizing hormone and forskolin in Leydig cells of adult rats. Endocrinology, 1992. 130(4): p. 2007-2015.

18. Payne, A.H.S., L.L., Multiple mechanisms for regulation of 3 beta-hydroxysteroid dehydrogenase/delta 5----delta 4-isomerase, 17 alpha-hydroxylase/C17-20 lyase cytochrome P450, and cholesterol side-chain cleavage cytochrome P450 messenger ribonucleic acid levels in primary cultures of mouse Leydig cells. Endocrinology, 1991. 129(3): p. 1429-1435.

19. Malaska, T.P., A.H., Luteinizing Hormone and Cyclic AMP-mediated Induction of Microsomal Cytochrome P-450 Enzymes in Cultured Mouse Leydig Cells. The Journal of Biological Chemistry, 1984. 259(19): p. 11654-11657.

20. Payne, A.H.O.S., P.J., Structure, Function and Regulation of Steroidogenic Enzymes in the Leydig Cell, in The Leydig Cell, A.H.H. Payne, M.P.; Russell, L.D., Editor. 1996, Cache River Press: Vienna, IL.

21. Rani, C.S.S.P., A.H., Adenosine 3'-5'-Monophosphate-Mediated Induction of 17alpha-Hydroxylase and C17-20 Lyase Activities in Cultured Mouse Leydig 
Cells is Enhanced by Inhibition of Steroid Biosynthesis. Endocrinology, 1986. 118(3): p. 1222-1228.

22. Freshney, R.I., Culture of Animal Cells. 4 ed. 2000, New York, NY: John Wiley and Sons, Inc.

23. Tremblay, J.J.R., N.M.; Lague, E., Nuclear Receptors, Testosterone, and Posttranslational Modifications in Human INSL3 Promoter Activity in Testicular Leydig Cells. Annals of the New York Academy of Sciences, 2009. 1160: p. 205212.

24. Hirata, Y.K., K.: Chen, H.C.; Milbrandt, J.; Guroff, G., The Phosphorylation and DNA Binding of the DNA-binding Domain of the Orphan Nuclear Receptor NGFI-B. The Journal of Biological Chemistry, 1993. 268(33): p. 24808-24812.

25. Qamar, I.G., E.Y.; Kim, Y.; Song, C.H.; Lee, H.J.; Chun, S.Y.; Lee, K., Antisteroidogenic Factor ARR19 Inhibits Testicular Steroidogenesis through the Suppression of Nur77 Transactivation. The Journal of Biological Chemistry, 2010. 285(29): p. 22360-22369. 